\title{
On Internal Phloëm in the Root and Stem of Dicotyledons.
}

\author{
BY \\ D. H. SCOTT, M.A., Ph.D., F.L.S., \\ Assistant Professor of Biology (Botany) Royal College of Science, London, \\ AND \\ GEORGE BREBNER.
}

With Plates XVII, XIX, XX.

\begin{abstract}
M ODERN botanical research, especially during the last W fifteen years, has sufficiently demonstrated the importance of that modification of the more ordinary type of dicotyledonous structure, which consists in the presence of phloëm on the medullary as well as on the cortical side of the vascular bundles. The term bicollateral, now generally used to express this arrangement of the vascular tissues, was first introduced by De Bary'.

The structure itself was discovered in Cucurbita by Th. Hartig ${ }^{2}$ in 1854 , and by von $\mathrm{Mohl}^{3}$ in the Asclepiadeae and other plants in the following year. From that time onwards internal phloëm has been observed in a constantly increasing number of natural orders. Owing chiefly to the investigations

1 Comp. Anatomy of Phanerogams and Ferns; Eng. ed. p. 338.

Botanische Zeitong, I854, P. 5 I.

I Bot. Zeitung, 1855 , p. 890.

[Annals of Botany, Vol. V. No. XIX. August 18gL]
\end{abstract}




\section{Scott and Brebner.-On Internal Phloëm}

of Russow ${ }^{1}$, Vesque ${ }^{2}$, Petersen ${ }^{3}$, and Solereder ${ }^{4}$, we are now able to form a fair estimate of the distribution of this character among the dicotyledonous orders, though it is almost certain that additions will still be made to the number of those which possess it. Taking Solereder's summary ${ }^{8}$ as the latest available, we find bicollateral bundles in the following orders: Polypetalae: Vochysiaceae, Melastomaceae, Myrtaceae, Lythraceae, Onagraceae, Cucurbitaceae ; also in some Combretaceae. Gamopetalae: Asclepiadaceae, Apocynaceae, Solanaceae, Gentianeae, Loganiaceae; also in most Convolvulaceae, and in some Acanthaceae. Apetalae: Thymelaeceae, Penaeaceae, Euphorbiaceae (sub. tribe Eu-crotoneae, \&c.), and in one genus of Polygonaceae. In the great majority of these eighteen orders, the character is constant throughout, with the occasional exception of a divergent tribe. For the systematic details Solereder's work must be consulted. We have not included the Cichoriaceae and Campanulaceae, in which the naturc of the medullary vascular tissues is open to some doubt.

Enough has been said to show that bicollaterality is a character widely prevalent among the most highly organized dicotyledonous families and of great systematic value. It may fairly be maintained, that these orders represent, in certain directions, the most advanced types of dicotyledonous structure.

3 Betrachtungen über das Leitbündel- nnd Grundgewebe; Dorpat, I875.

2 Anatomie comparée de l'écorce; Annales des Sciences Nat, Bot. Sér. 6, T. II. I875.

3 Ueber das Auftreten bicollateraler Gefässbündel; Engler's Jahrbuch für Systematik, Bd. III. I882.

- Ueber den systematischen Werth der Holzstractar bei den Dicotyledonen; Miinich. 1885 .

- Loc. cit, p. 28 . We are not aware of any additions to the list since, unless it be the Basellaceae, a family of climbers allied to the Chenopodiaceae, investigated by Morot and not mentioned by Solereder; see Morot: Note sur l'Anatomie des Basellacées, Bulletin de la Soc. Bot. de France, vol. 3I, I884. Medullary phloèm, accompanied by rylem, has forther been found by Dangeard in Acanthophyllum (Caryophyllaceae); by Robinson in lades (Phytocreneae), and by ourselves in Acantholimon (Plumbagineae); bat these formations are allied rather to those in the pith of Tecoma than to the internal phloem of bicollateral bundles: see Dangeard, Monographie anatomique des Acanthophyllum, Le Botaniste, 1889, p. I94; Robinson, on the stem-structure of Iates tomericlla, \&cc., Annales da Jardin botanique de Baitenzorg, vol. VIII. p. 95, I89o... . 
The physiological importance of bicollaterality cannof be fully estimated until the general question of the functions of the phloëm has been finally determined, but it is undoubtedly great. The sheltering of a portion, often the larger portion, of the delicate phloëm within the woody cylinder is an obvious advantage, as is also the fuller utilization of the pith-area and consequent concentration of the tissues generally. It is probable also, that the pith-cells themselves may be able to discharge both storing and conducting functions more efficiently when brought into direct relation with the phloëm and its proteid contents.

All such speculations are of necessity premature, but in the mean time the due consideration of these modified arrangements may guard us against erroneous views of the functions of. the phloëm, which might be entertained, if we limited our attention to so-called normal structure. To this point we shall return.

The primary object of our work was to investigate the structure of the root in plants, which have bicollateral bundles in the stem and its appendages. Our observation of medullary phloëm in the root of Strychnos ${ }^{1}$ rendered it probable, that in other plants a similar continuity of structure between root and shoot might be traced. In order to estimate the significance of any anatomical character it is evidently necessary to know, whether it extends throughout the plant or is limited to special regions. As regards the more modified dicotyledons, however, our knowledge of their characteristic structure is often confined to the subaërial organs. And if, as we fully expected to find, medullary phloëm as such, proved in many cases to be absent from the root, it was still desirable to trace its course in the transitional region, and to see whether it ended blindly or became in any way continuous with the normal phloëm of the root.

This point has been very little attended to by anatomists. Gérard traced the course of the bundles from root to stem in two Solanaceous plants and in Cucurbita. He found that the

${ }^{1}$ On the Anatomy and Histogeny of Strychizos, Annals of Botany, vol. III. p. 29I, 1889. 


\section{Scott and Brebner.-On Internal Phloem}

normal phloëm-strands of the root give off branches, some of which pass into the pith and are continuous with the internal phloëm of the stem. He figures the transitional region in Datur $a^{1}$. Fischer described very fully the transition from stem to root in Cucurbita. He shows clearly how the internal phloëm of the stem passes to the outside of the primary xylem and for some distance forms a ring between the latter and the secondary wood, gradually disappearing lower down, but long remaining traceable in the medullary rays. His statement that the transitional phloëm-ring between primary and secondary xylem ends blindly below, gives, we think, a wrong impression. He purposely limited his investigation to a much thickened axis, and this fact somewhat impairs the clearness of his results ${ }^{2}$. Lastly Dangeard, who has most recently investigated the mode of union of root and stem, merely states that in the Convolvulaceae the internal phloëm accompanies the cotyledonary traces as far as their lower extremity in the hypocotyl, a statement which throws little light on our subject ${ }^{3}$.

Our most interesting information on the roots of plants with bicollateral stem-structure is due to Weiss ${ }^{4}$, who has shown that in many of these plants, and especially those with fleshy roots, the parenchymatous xylem of the latter contains strands of phloëm, produced internally by the cambium. This interxylary phloëm in the root was found by him in various Onagraceae, Gentianeae and Solanaceae, and he considers it a characteristic peculiarity of plants with medullary phloëm in the stem.

Our observations extend those of Weiss, and may perhaps throw some further light on the relations between the two

1 R. Gérard, Passage de la racine à la tige; Ann. des Sci. Nat. Bot. Sér. 6, T. XI. I881, pp. $358,376, \mathrm{Pl} .18$, Fig. 54

Fischer, Siebröhrensystem der Cucurbitaceen; Berlin, 1884, p. 53, P1. VI. Fig. I4.

- Dangeard, Recherche sur la mode d'union de la tige et de la racine; Le Botaniste, vol. I. 1889 , p. r Io.

- J. E. Weiss, Anat. and Physiol. d. fleischig verdickten Wurzeln ; Flora, I880; Markstaindige Gefässbiindelsystem und Blattspuren; Bot. Centralblatt, vol. I5, I883, pp. 397, 409 . 
in the Root and Stem of Dicotyledons. $\quad 263$

structures. Weiss in his second work lays stress on the distinction between medullary phlö̈m and medullary bundles. The former is simply the internal part of the phloëm in the bicollateral bundles. The medullary bundles (which possess or may possess xylem as well as phloëm) are an independent system and usually represent the lower ends of the leaftraces, which have already passed down one or more internodes as part of the normal ring. The distinction, plain enough in the extreme cases, is by no means obvious in all, for on the one hand the medullary phloëm of bicollateral bundles may be widely separated from its xylem, while on the other hand the medullary bundles often consist of phloëm-strands only. Weiss states that the medullary phloëm as distinguished from the independent medullary burdles may be recognized by the following characters:-

I. The medullary phloëm-strands in Solanaceae, Asclepiadeae, Apocynaceae, Gentianeae, Convolvulaceae, Vochysiaceae, Cucurbitaceae, \&c., in every case accompany the leaftraces, within which they lie, on their exit into the leaf.

2. They arise almost at the same time with, or only a little later than, the parts of the phloëm outside the xylem.

3. Where a cambium forms in connection with them, it never produces wood also, as it does in the medullary bundles of some of the Cichoreaceae and Campanulaceae, and in Tecoma, Acanthus, \&c. ${ }^{1}$.

This last distinction (3) was originally due to Vesque ${ }^{2}$. It is a merely empirical generalization and, as might have been expected, has proved not to hold good. The other differences are of value, though their application is not always easy.

Plants with medullary burdles in the stem may also have interxylary phloem in the root, as in various Cruciferae (e. g. Cochlearia). In the typical cases each phloëm-strand in the root is surrounded by xylem-elements, forming a tertiary concentric bundle. These structures arise at a distance from the normal

1 Markständiges Gefässbïndelsystem, loc. cit., p. 396 .

- Loc. cit. Vesque speaks of false cambium in these cases. Sce our sabsequent observations on Apocynum and Willughbeia. 


\section{Scott and Brebner.-On Internal Phlö̈m}

campium in the older secondary xylem. Weiss regards them as the direct downward prolongation of the medullary leaftrace bundles of the stem ${ }^{1}$.

In the course of our work various facts of interest connected with bicollateral structure were observed in the stem as well as in the root, and beyond this, we were led to examine one plant (Acantholimon), which does not possess bicollateral bundles in the strict sense at all, though it has analogous peculiarities. Hence, our field of work is not very strictly defined. The present paper is only a beginning of the subject. Many important orders are entirely untouched, and there is clearly room for much further investigation, for which we have already some materials.

The following observations then may be grouped under two heads :-

I. The relation between stem and root-structure in plants with bicollateral bundles.

2. Special modifications of the stem-structure in plants, which belong to this category or present a similar arrangement of tissues. Observations closely connected with the subject before us will be found in the preceding paper on Ipomoea versicolor ${ }^{2}$, which for reasons of convenience has been dealt with separately.

We adhere to the term bicollatcral butndles in spite of the strong objections to its use which have been urged by Hérail. This author rejects De Bary's terminology on the ground that it is only really appropriate to a single family, the Cucurbitaceae. In the majority of the plants in question, he finds that the medullary phloëm does not appear at the same time as the rest of the bundle and does not proceed from the same meristem. It is especially on this second point, the independent position of the internal phloëm, that he insists. His contention is supported by observations on the Solanaceae, Asclepiadeae, A pocynaceae, Myrtaceae, \&c. ${ }^{3}$ Without entering

' Markstindiges Gefässbündelsystem, loc. cit., p. 406.

2 See p. 173 of the present volume of the Annals of Botany.

- Hérail, Etude de la tige des Dicotylédoncs; Ann. des Sci. Nat. Bot. Sír. ?, vol. II. 1885 , p. 267 . 
into a detailed criticism of his statements we may admit at once that his vicw is so far justified, that in many cases the medullary phloëm groups show no clear relation, as seen in transverse section, to individual vascular bundles. But their longitudinal course shows sufficiently to which bundle or system of bundles they belong. The term vascular bundle itself does not always or even generally represent a welldefined unit. The idea is taken from certain plants, especially Monocotyledons, in which the strands of associated tracheac and sieve-tubes are really distinct. Botanists have found it convenient to extend the idea to vascular tissue generally, although in a large number of the higher dicotyledons, so far at least as the stem is concerned, the limits between the bundles may be impossible to trace. And so it is with the special case of bicollaterality. So long as an internal phloëmstrand has the same longitudinal course as the neighbouring bundles of the leaf-trace there is no serious objection to regarding them as parts of the same formation. We do so, however, rather as a matter of convenience than of principle and without cxpressing any general opinion as to the order of development, which certainly varies in different cases.

\section{Relation between Stem and Root-structure} in Plants with bicollateral Bundles.

I. Brozuallia viscosa, H. B. and Kth. (Salpiglossideae). The bicollateral structure of the vascular bundles in many Salpiglossideae has been demonstrated by Vesque, Petersen, and Solereder. The two last-named authors have pointed out that this anatomical character, which appears to be constant for the tribe, seens to confirm the opinion of Bentham and Hooker, that these plants belong to the Solanaceae rather than to the Scrophulariaceac. Brozvallia itself was among the genera investigatcd by Peterson ?

In the above species, the transvcrse scction of a young

$$
1 \text { Loc. cit., p. } 3^{82 .}
$$


stem (in which the secondary wood averages six elements in radial thickness) shows a ring of numerous small groups of internal phloëm, each group of about the size of one of the smaller cells of the pith. All the groups lie at some distance within the protoxylem of the bundles, from which they are separated by at least two parenchymatous cells, usually more. The phloëm in the pith is collectively greater in amount than that in the normal position. The medullary groups are entirely confined to the outer small-celled zone of pith. In an older stem, with wood about thirty cells thick, the. medullary phloëm-groups have increased somewhat in bulk, divisions taking place in the adjacent cells so as to add new elements to the phloëm. There is, however, no regular internal cambium in this plant and the groups remain isolated. The external phloëm receives slight additions from the normal cambium, but its proportion to the internal phloëm is littlc affected. It is worth pointing out incidentally, that the stem has a beautifully clear endodermis with the characteristic dots on the radial walls. This is continuous, through the hypocotyl, with the endodermis of the root.

The main root is diarch and shows perfectly typical structure, without any pith (see Fig. 5). Sections of older roots show that secondary thickening goes on in the usual manner. This, then, is a plant in which the medullary phloëm of the stem has completely disappeared in the root. It remains to trace its downward course and to determine its relation to the normal phloëm-groups of the vascular cylinder of the root. The transverse section of the hypocotyl shows six bundles. Of these, two opposite pairs are the cotyledonary traces (see Fig. I), The bundles of each pair have their protoxylem-groups turned towards each other. The two remaining bundles, lying between the two cotyledonary pairs, proceed from the leaves above the cotyledons. They disappear lower down, anastomosing with the cotyledonary traces. It is the latter only which are directly continuous with the xylem of the root. The pith is small compared to that of the epicotyledonary stem. It contains a number 


\section{in the Root and Stem of Dicotyledons. 267}

(10-12) of phloëm groups. Some of these are placed opposite the primary xylem of the bundles, but on the whole there is little regularity. Their distance from the protoxylem-elements also varies, some of the groups lying near the centre of the pith. It is noticeable, that in the hypocotyl the number of internal still exceeds that of external phloëm-groups, the dimensions of each group being about equal.

On tracing the hypocotyl downwards to the tap-root, the changes which we find in the position of the tissues are as follows ${ }^{1}$ :- The pith gradually thins out; the two lateral bundles disappear, becoming confluent with those of the cotyledons. The primary xylem-groups of each cotyledonary pair approach each other and ultimately unite, turning their protoxylem outwards. In the transitional region the strands of internal phloëm successively pass out between the converging xylem-bundles and one by one reach the strands of external phloëm, with which they fuse. The external phloëm-strands concentrate themselves on the two sides of the vascular cylinder, between the two centripetal xylem-groups, which now represent the cotyledonary pairs. Finally, these two groups themselves unite at the centre of the root, forming the diarch xylem-plate, and at this point the last of the internal phloëm-strands passes out and joins the normal phloëm.

So far we have considered the course of the primary bundles without reference to the occurrence of secondary growth. In the upper part of the hypocotyl, the cambium, being formed immediately outside the primary xylem, lies necessarily far outside the internal phloëm-groups. Lower down, where some of these groups on their outward course are already level with the xylem, the eambium forms in contact with their outer surface. Then we come to the critical region of transition, where the internal approaches the external phloëm, and here it is plain, that for a certain distance the cambium must actually cut through the outgoing strand. Lower down

\footnotetext{
${ }^{1}$ It can hardly be necessary to explain that the socceeding description relates simply to the course of the bundles and has no reference to developmental changes.
} 
still, where the fuslon with the external phloëm is complete the cambium appears in its typical position entirely within the phloëm.

The figures $\mathrm{I}$ to 5 are selected from a series of 140 successive transverse sections. Fig. I shows the structure of the hypocotyl above the point where the internal phloëm has begun to pass out, or at least before any of it has passed beyond the primary xylem. In Fig. 2 the pith is already much smaller, and three of the internal phloëm-strands are shown on their outward course, having already passed the primary xylem-groups ${ }^{1}$. In Fig. 3 the pith is still smaller, much of the internal phloëm has passed out, and one large group is seen imbedded in the secondary wood outside one of the cotyledonary traces. Fig. 4 is from a region, where the minute pith is almost entirely occupied by such internal phloëm, as has not yet made its exit. The xylem of each pair of cotylcdonary bundles is here united into a single group, and beyond one of the two groups thus formed, a phloëm-strand is shown, on its way to join its neighbours outside. Lastly, Fig. 5 shows the typical rootstructure. The two cotyledonary xylem-groups here form a single diarch plate. There is no pith, and all the phloëm has become external.

It will be seen that the sections were taken from a plant, which, though young, already showed some secondary thickening. We have stated above, that at certain points of the transitional region the cambium crosses the outgoing phloëmstrand. The question arises: does the cambium at these points form lignified secondary wood, so as completely to interrupt the continuity of the intcrnal and external phloëm, or does it keep up this continuity by the interposition of secondary phloëm-elements? We have no doubt that the latter is the truth. In the sections drawn, some of the elcments of the outgoing strand are most probably of secondary

1 It would $e$ just as correct to speak of the xylem passing inwards as of the internal phloëm passing outwards, the question being simply one of relative position. The description given in the text is, however, prefernble, for the point to be emphasized is the ultimate junction of the internal with the external phloëm. 
origin (see for example Fig. 3), and in other cases the imbedded phloëm-group is connected with the cambium by thin-walled tissue, as is shown clearly in Fig. 4.

Other sections through the transitional region of an older plant, with a thick zone of secondary wood, showed phloëmgroups imbedded in the latter, at a distance from the primary tissues which left no doubt as to their origin from the cambium. We conclude, therefore, that the phloëm of the rootsystem remains in permanent, and not merely in transitory, connection with the medullary, as well as with the external phloëm of the sub-aërial organs.

As regards the main points Browallia may be taken as a type of those plants which have medullary phloëm in the stem, but have normal roots. Further information on the points discussed will be found in the paper on Ipomoea versicolor. Our observations agree essentially with those of Gérard, above cited. He traced the transition in the opposite direction, namely from root to stem.

2. Asclepias obtusifolia, Mx. The Asclepiadeae are among the plants in which the bicollateral structure is best known So far as the stem is concerned the above species presents nothing remarkable. The internal phloëm is in the form of a ring of very numerous groups, which remain isolated from one another. They are not localized exclusively opposite the protoxylem-groups, but also border on the interfascicular tissue: They are generally separated by two or three parenchymatous cells from the xylem-elements. The internal phloëm, although not so great in amount as in some other plants, is extremely well developed, the sieve-tubes and the companion-cells being large and charactcristic. There are occasional divisions in the cells bordering on the groups externally, but no considerable cambial increase takes place. Petersen's ${ }^{1}$ Fig. 26 (from A. princeps) gives a fair idea of the structure of one of these groups, but in our plant there are more sieve-tubes in each. The diameter of a sieve-tube is often as much as $.03 \mathrm{~mm}$.

\footnotetext{
1 Loc. cit., Pl. VII.
} 


\section{Scott and Brebner.-On Inlernal Phloèm}

The external phloëm is considerable in amount, but is largely parenchymatous; the sieve-tubes are similar in size to those of the interior, and in a stem $I \mathrm{~cm}$. in diameter are scarcely more numerous.

As regards the root, the early stages are normal, with a diarch or triarch vascular cylinder. But all roots, which attain a diameter of much more than $1 \mathrm{~mm}$. have groups of phloëm in the wood. In a root about $3 \mathrm{~mm}$. in thickness, such as that from which Fig. 6 is drawn, much the greater part of the phloëm is situated in the wood. In roots of this size periderm has not yet formed, though the external cortex is withering away, and the vascular cylinder forms the bulk of the root. The secondary tissues are extremely parenchymatous and the cells crowded with starch; xylem- and phloëm-parenchyma are quite similar, and the isolated phloëm-groups in each arise in the same way by the sub-division of cells cut off respectively on the inner and outer side of the cambium. On the xylemside the parenchyma consists, partly of the medullary rays, partly of xylem-parenchyma in the narrower sense. Except in the form of the cells, there is no difference between the two, but the phloëm-islands appear to be limited to the latter. As regards the distribution of the interxylary phloëm, some of the groups are in contact with the protoxylem-elements. These groups have arisen, at any rate in part, from primary parenchyma. Otherwise the phloëm-islands are all secondary. Some of them lie at the sides of the groups of tracheae, which are scattered about among the parenchyma In this case cambial divisions take place on the side towards the tracheae, and we have the same structure which Weiss figured in Bryonia ${ }^{1}$. Other phloëm-groups are isolated in the secondary parenchyma remote from the tracheae. No considerable cambial growth of the phloëm-islands takes place. The neighbouring cells divide and add a few more sieve-tubes to the strand, but there is no obliteration of the older elements. The long-continuing divisions show that the development of the phloëm-island is a

\footnotetext{
1 Loc. cit., Flora, I88o, Fig. 6.
} 
gradual one, and is not completed until the group has been left far behind by the main cambium (Fig. 6).

The elements of the phloëm of the root resemble those of the stem, but the joints of the sieve-tubes are often very short. The transverse walls both of the external and of the interxylary sieve-tubes may be horizontal, bearing a single sieveplate, or inclined, in which case they show a series of plates. In size the interxylary are quite equal to the external sievetubes, both often exceeding ${ }^{\circ} 3 \mathrm{~mm}$. in diameter.

Roots $\mathrm{I} \mathrm{cm}$. thick show essentially the same structure. By this time a pericyclic periderm has been formed. The xylem is more parenchymatous than ever. Not only has an immense amount of fresh parenchyma been added by the cambium, but the older parts have undergone dilatation, which starts from several centres and leads to the obliteration of some of the elements. This process is accompanied by the formation of new strands of phloëm by the subdivision of cells in the dilated xylem-parenchyma.

The interxylary phloëm-groups of the root then may arise in three different ways :-

I. By the division of cells of the primary conjunctive parenchyma.

2. By direct centrifugal development from the cambium.

3. By late division of cells of the older secondary xylemparenchyma long after its origin from the cambium.

We might for convenience distinguish the three varieties as primary, secondary, and tertiary phloëm-islands. From what has already been said, it will be clear that the distinction between them is not always quite a sharp one.

In the thicker roots horizontal or oblique anastomoses ot the interxylary phloëm-strands are often found.

The transition from stem to root could only be examined in an old plant, as no seedlings were available. For one or two internodes above the hypocotyl the wood of the stem contains minute phloëm-islands. They extend up as far as the wood remains parenchymatous, generally occurring near the groups of tracheae. Careful study of successive sections led to the 


\section{Sçott and Brebner.-On Internal Phloëm}

conclusion that these interxylary phloc̈m-strands end blindly above, and are not continuous in that direction with any of the phloem-systems of the stem. The lower part of the stem is in fact to be regarded as an extension of the storing-tissues of the root, and the phloëm-strands may serve for the conduction of proteid food-materials from one part to the other.

Starting from one of the lowest internodes and tracing the tissues downwards the following changes are observed: The wood becomes more and more parenchymatous, i. e. nearly all its elements except the scattered vessels come to have cellulose walls and starchy contents. The interxylary phloëmstrands become larger and more numerous. The medullary phloëm-strands ramify and at a certain stage are found crowded all over the pith, which gradually becomes smaller, some of them reaching its centre. In the mean time the primary xylem-groups approach the middle of the axis ultimately fusing to form the diarch xylem-plate of the root. Thus some of the medullary phloëm-groups, and ultimately all of them, pass to the outside of the primary xylem. There is no doubt, that the more central phloëm-groups of the main root are the direct downward continuation of the medullary phloëm of the stem ${ }^{1}$. The process is so far essentially the same as in Brozvallia. But in Asclcpias the medullary phloëm does not pass entirely to the outside of the cambium. It passes, in part at least, straight down the root, adjacent to the primary xylem, and thus forms the first ring of phloëm-islands. The rest of the interxylary phloëm is of secondary or tertiary origin as described above. Some light is thus thrown on the frequency of phloëm-islands in the roots of plants with bicollateral bundles in the stem. The medullary phloëm of the stem becomes the interxylary phloëm of the root. The formation of interxylary phloëm by the cambium is not a new departure, but an extension of the primary structure. The phloemstrands, whatever their origin, are connected by anastomoses.

Our results agree in many points with those obtained by 1 Just as Weiss found in Oenothera, loc. cit.; Bot. Centralblatt, XV. p. 4o9. 
Weiss in various Onagraceae, Gentianeae, and Solanaceae ${ }^{1}$. $\mathrm{He}$, however, found that the interxylary phloëm was always formed directly from the cambium, and that the groups never increased subsequently by a special cambium of their own. In Asclepias, as we have seen, phloëm-islands may be formed in tissues far removed from the cambium, while the groups constantly show cambial growth themselves, though not on a great scale. The sharp distinction, which Weiss endeavours to draw between his interxylary bundles and interxylary phloëin so far falls to the ground.

3. Thladiantha dubia, Bunge (Cucurbitaceae). We take this plant next, because, though systematically so remote from Asclepias, it presents certain analogies with that genus as regards the points under consideration. The bundle-system of the stem is of the usual Cucurbitaceous type and is shortly described by De Bary ${ }^{2}$. The internal phloëm, which is not very greatly developed, is connected with the external mass by sieve-tubes in the medullary rays, as happens in other Cucurbitaceae ${ }^{3}$. There is a distinct interfascicular cambium ${ }^{4}$.

Some of the roots ${ }^{5}$ have very curious tuberous swellings, to the structure of which we will return. But first the more ordinary root-structure must be described. The bundlecylinder is most often tetrarch, but this is not constant, and indeed the same root may pass from hexarch to tetrarch structure in various parts of its course. The roots have no pith, the primary xylem-bundles often meeting in one or two large central vessels. A group of bast-fibres lies outside each of the primary phloëm-masses, as in the Leguminosae. As the root grows in thickness the bast-groups break up into a

${ }^{1}$ Loc. cit. Flora, 1880, p. 97, and Bot. Ccntralblatt, XV. p. 408.

${ }^{2}$ Loc. cit., p. $24^{8}$.

- De Bary, loc. cit., p. 338. We have occastonally found a few small sieve-tabes in the secondary rays also.

- Cf. M. C. Potter, On the incrense of the thickness of the stem of the Cucurbitncene; Proc. Cambridge Phil. Soc. vol. VII. p. 4.

s Some of the peculiarities of these roots have already beèn described by Datailly, Sur quclques phénoménes détcrminés par l'apparition tardive d'éléments nouveaux dans les tiges et les racines des Dicotylédones. Paris, $1879, \mathrm{Pp} .37$ and 39. 


\section{Scott and Brebner.-On Internal Phloèm}

number of separate strands, as indicated in the diagrammatic Fig. 7. The periderm is pericyclic.

When secondary thickening begins, the cambium, as so often happens, forms secondary parenchyma opposite the protoxylem and true wood only opposite the phloëm. The parenchyma may either be continued indefinitely by the cambium as a ray, or woody elements may be formed closing it in. As -growth in thickness goes on, this process is repeated. New rays originate at the middle of each prominent xylem-mass and these also may be discontinuous, the wood closing in over them. Fig. 7 shows a typical case with the secondary rays only just beginning. In Fig. 8, the secondary ray shown is partly closed in. Considering the position of the parenchyma, analogy has led us to speak of it as forming rays, but when it becomes enclosed in wood the expression xylem-parenchyma would be more appropriate. The normal phloëm is well developed, the sieve-tubes attaining the large diameter of $045 \mathrm{~mm}$. But phloëm is also formed on the inside of the cambium. In the earlier stages it is limited to the ray-parenchyma. Some of the interxylary sieve-tubes are always situated at the beginning of the principal rays. Some of these are perhaps of primary origin. Others are scattered about near the sides of the ray. As soon as the secondary rays are started, phloëm is formed in them also (see Figs. 7 and 8). Sometimes a nascent ray becomes almost at once enclosed in wood and in these cases the whole of the little parenchymatous group may be used up to form a phloëm-strand. Some of the interxylary sieve-tubes are formed directly from the cambium; others are differentiated later on in tissue which is already remote from it, so that here again the two processes distinguished by Weiss occur in the same root. The interxylary groups are small, in fact a single sieve-tube with its companion-cells is often isolated. The cells surrounding the phloëm show a few divisions, but no considerable growth takes place in this way in the non-tuberous part of the root. The interxylary sieve-tubes are not so large as the external ones, but reach $.03 \mathrm{~mm}$. in diameter. 
The root-tubers grow to an enormous size. They form, huge irregularly rounded swellings, which are often between two and three inches $(5$ to $7.5 \mathrm{~cm}$.) in diameter. The root above and below them is cylindrical and not more than about 5 $\mathrm{mm}$. thick. The root-tubers are deeply furrowed in the longitudinal direction. The furrows, which are usually four in number, correspond in position to the four primary xylemgroups of the root, the ridges between them to the primary phloëm. As compared with the ordinary root, the tubers show most interesting changes of structure consisting (I) in increased centrifugal activity of the normal cambium, with production of an excessive amount of parenchyma, the rays bearing a large proportion to the wood; (2) in enormous dilatation of the pre-existing parenchyma, especially in the region immediately surrounding the primary xylem. This dilatation results in the breaking up of the inner lignified portions of the secondary wood into isolated strands imbedded in parenchyma. Often the dilatation of the tissues bordering on the primary xylem nips off, as it were, the outer ends of the xylem-plates. Where this happens the protoxylem may be carried by the continuous extension of the tissues behind it, far out into the surrounding parenchyma. The result is very curious. In one case two out of the four xylemplates were unaffected and remained in their original position. In a third xylem-plate the dilatation had separated off the outer part at a rather late stage, so that the protoxylem was only carried a little way out. The fourth protoxylem-group however had been nipped off quite early, and was now stranded in the parenchyma at a distance from the rest of the primary xylem equal to many times the diameter of the original vascular cylinder. During the dilatation every isolated group of lignified tissue forms a centre around which active cell-division goes on, and owing to these local meristematic regions the dilated parenchyma loses all trace of its former regular radial arrangement. The growth of the tuber is accompanied by a great increase in the amount of its interxylary phloëm. The tertiary phloëm-bundles are especially 


\section{Scott and Brebner.-On Internal Phloëm}

crowded around the middle of the root in the rcgion where dilatation has chiefly taken place. They are also massed along the margins of the isolated strands of. secondary lignified tissue, but are by no means limited to the neighbourhood of woody elements.

As the dilatation of parenchyma goes on chiefly in the inner part of the root, the outer region of the xylem is the more woody. Here we find, immediately within the cambium, a series of woody wedges (containing the tracheae), separated from each other by broad parenchymatous rays. They are arranged usually in four groups, corresponding in position to the primary phloëm-bundles. As the root-tubers increase in thickness the course of both xylem- and phloëm-strands becomes very oblique, with frequent anastomoses. The development has been traced in detail up to a diameter of about half-an-inch $(1.25 \mathrm{~cm}$.). The further growth of the root-tuber appears to be chiefly due to dilatation. Almost the whole tissue in the old specimens is parenchymatous, the wood being almost limited to a narrow zone just inside the cambium.

This root shows with remarkable clearness the characteristic changes involved in the assumption of this type of fleshy structure. Complicated as the final condition is, it is casy to refer it to its origin from a comparatively normal dicotyledonous root-structurc.

We have not, in this plant, specially investigated the transition from root to stem, but we have no doubt that here, as in Asclepias, the innermost interxylary phloëm of the root is continuous with the medullary phloëm of the stem.

Altogether this root has much in common with that of Asclepias, the most essential distinction lying in the different relation of the interxylary phloëm to the 'medullary' rays.

Sieve-tubes in the xylem have been observed in the root of Cucurbita by Van Tieghem ${ }^{1}$ and Fischer ${ }^{2}$. From the description of the latter they seem to be limited to the transitional region. He rcgards them as forming the downward continuation of the sieve-tubes found in the medullary

1 Ann. des Sc. Nat. Bot. Sér. 5, vol. XIII. p. 215 . $\quad$ Loc. cit., p. 53. 
rays of the hypocotyl. The interxylary phloëm-system of Thladiantha is beyond comparison more highly developed a fact correlated no doubt with the presence of the root-tubers.

The interxylary phloëm in our plant differs from that in Bryonia $^{1}$, (I) in the fact that it is in part formed directly from the cambium, (2) in having no constant relation to the tracheae.

4. Chironia peduncularis, Lindl. (Gentianeae). In this genus the existence not only of the medullary phloëm, which is usual in the order, but also of phloëm-strands imbedded in the wood, was discovered by Vesque ${ }^{2}$ in 1875 . The species observed by him was $C$. linoides. His observations were extended by Solereder to $C$. baccifera and to Orplizim frutescens $^{3}$. We have been able fully to confirm the statements of these authors in the species examined by us. The medullary phloëm forms a ring of scattered strands separated by a few cells $(\mathrm{I}-3)$ from the inner margin of the wood. Opposite the larger bundles the phloëm-strands may form a double row. The external phloëm is not much developed. In a stem, where the secondary wood was quite thirty elements in radial thickness, the normal phloëm had received scarcely any increase from the cambium. The groups of sieve-tubes are both smaller and less numerous than those in the pith, and the individual sieve-tubes are also smaller. In the external phloëm $015 \mathrm{~mm}$. is a maximum diameter for the sieve-tubes, while in the internal strands $022 \mathrm{~mm}$. is commonly attained.

The examination of sections from near the apex proves that the medullary phloëm is formed somewhat later than the external. The first medullary strands to be formed are those just within the large bundles, and here they reach their greatest development. Later on, phloëm-strands are also differentiated on the inner side of the smaller bundles and the interfascicular tissue. As a rule it is not until two or three xylem-elements have been fully formed in each bundle, that

1 Weiss, loc. cit., Flora, 188o, p. Iog.

2 Loc. cit., p. I46, Pl. 10, Figs. 3 and 4 . Soc. cit., p. 181. 


\section{Scott and Brebner.-On Internal Phlö̈m}

the corresponding medullary phloëm-groups arise. Each group is formed by the subdivision of an elongated cell of the young pith, or more than one such cell may take part in the process. Chironia then is a plant to which Hérail's objection to the term bicollateral would be especially applicable. The internal phloëm arises late compared with the rest of the bundle and not, strictly speaking, from the same procambial strand ${ }^{1}$. But to these differences we are not disposed to attach great importance. The medullary phloëm accompanies the bundles on their exit to the leaf and only disappears in the finer branches ${ }^{2}$.

The interxylary phloëm-strands begin to be formed when the secondary wood is about fifteen elements thick. They are similar to those in the pith, only more regular owing to their cambial origin. We have satisfied ourselves that Vesque is right in stating that they are developed on the inner side of the cambium, so here we have a case of centrifugal interxylary phloëm as contrasted with the centripetal development in Strychnos. These phloëm-islands are formed in great numbers. In a thickened stem the normal phloëm is quite insignificant in amount compared to the medullary and interxylary systems jointly.

Before we leave the stem it may be pointed out that here also there is a typical endodermis and uniseriate pericycle, both of which are easily recognised even in the thick stems.

So far as we know no observations have previously been made on the root of Chironia. A thickened root has the structure represented in Fig. 9. The cortex, which is not thrown off by periderm, is very lacunar; it shows a distinct exodermis. Its innermost layer, the endodermis, undergoes radial cell-division, enabling it to keep pace with the growth of the vascular cylinder within. The pericycle is one or two layers in thickness. The external phloëm is only moderately developed. The xylem-cylinder is dotted over in all parts

1 Oar observations on the development of Strychras may be contrasted with this. See Annals of Botany, vol. III. p. 28I, Pl. XVIII. Fig. I.

. Cf. Weiss, loc. cit., Bot. Centralblatt, XV. p. 401. 
with phloëm-islands, which collectively far exceed in area the normal phloem. Of these interxylary strands the more external lie entirely in the secondary wood. Others, however, occur on a level with the primary xylem, and in - many roots, though not in all, there is a central phloëm-strand occupying the small pith-area. When this is absent the xylem-groups meet in the middle.

Tracing the development, we find that the bundle-system is polyarch, the number of xylem- and phloëm-bundles variable, often as many as ten of each.

For a time the protoxylem-groups alone represent the wood, often with one vessel only to each bundle, the protophloëm appearing between them as usual. Later on the centripetal development of the primary xylem goes on, but its inner and later-formed portion is as a rule separated from the protoxylem by a few cells, which remain parenchymatous. The further development of the primary xylem is accompanied by the formation of phloëm-strands among the lignified cells, so that the more internal phloëm is of primary origin. The strands situated on the margin of the primary xylem may subsequently receive additional elements from the cambium (Fig. 10, $p h^{3}$ ). The root shown in Fig. 9 has an approximately central phloëm-group $\left(p / h^{2}\right)$, the origin of which is evidently altogether primary.

The secondary thickening of the root presents a striking peculiarity, which has not, so far as we are aware, been noticed elsewhere. In ordinary dicotyledonous roots, as has long been known, the cambium first arises within the primary phloëm, by divisions of the cells of the conjunctive parenchyma. It then extends round the exterior of the xylem-plates, the pericyclic cells dividing to complete the cambium outside the protoxylem. In Chironia however, the cambium is, as a rule, formed inside the protoxylem-groups, which are thus for a time completely cut off from the rest of the wood. This, 'then, is the function of the parenchyma, which remains unlignified between the protoxylem and the more internal wood. It divides to complete the cambial, ring (see Fig. 10, px). 


\section{Scott and Brebner.-On Internal Phloëm}

As the activity of the cambium goes on, the isolated protoxylem-elements are pushed further and further outwards, accompanying the external phloëm ${ }^{1}$. Often this proceeds until a large amount of secondary wood has been formed, as in the root shown in Fig. 9, where two protoxylem-elements are seen outside the cambium. Sooner or later, however, the protoxylem is restored to the main body of the wood, from which the cambium had severed it. Sometimes this happens very soon (Fig. II), sometimes very late (Fig. 9), and it takes place very irregularly. Thus in Fig. 9, between the two isolated protoxylem-elements is a third, which has long been enclosed in secondary wood. It is difficult to distinguish, but is probably the element marked with letter $a$. The enclosure of the protoxylem in the wood happens as follows: the cambial divisions within it cease, the cells lying just to the outside begin to divide and complete the cambial ring; new wood is formed and the protoxylem-element is now left behind, imbedded in secondary wood (cf. Fig. II). Ultimately all these elements are thus regained by the wood. As is often the case in roots, the protoxylem-vessels are not spiral but reticulate. Their thickening is sufficiently different from that of the pitted vessels of the secondary xylem for them to be recognised long after their enclosure in the latter. Since we made these observations we have found the same mode of development in the root of an Impatiens, in which the protoxylem is also cut off by the cambium from the wood.

We traced carefully the development of the secondary phloëm-islands of the root. Here, as in the stem, they are formed centrifugally, on the inner side of the cambium. A cell cut off from the latter divides two or three times by tangential or inclined walls. The products of division are the mother-cells of sieve-tubes. They then divide again to form their companion-cells and the phloëm-strand is complete (see Fig. 12). The development can be studied with advantage in radial longitudinal sections, which also leave no

1 It is a curious coincidence, though certainly nothing more, that the same root should show phloëm-strands in the xylem and xylem-strands in the phloëm. 
in the Root and Stem of Dicotyledons. $28 \mathrm{I}$

doubt that the cambium lies to the outside of the sieve-tubes all through.

Chironia and Strychnos are the only genera in which we have at present found strictly medullary phloëm in the root, phloëm, that is, which lies altogether within the primary xylem. In both cases its presence is somewhat inconstant. On the whole the agreement in structure between root and stem is exceptionally manifest in Chironia. The material at our disposal did not permit of our tracing the actual transition from the one to the other, for all the roots available were adventitious. As regards the connection of these roots with the stem, we found that the interxylary and medullary phloëmstrands of the adventitious root are continuous with the interxylary phloëm of the stem, but there is no direct communication with the medullary phloëm of the latter.

In Gentiana acaulis, L., which we also examined, the root, though very parenchymatous, showed no internal or interxylary phloëm. In other Gentianeae, however, peculiarities resembling those of Chironia and Orphizm have been observed. Thus Arthur Meyer in his admirable monograph of Gentiana lutea ${ }^{1}$ describes sieve-tubes in the secondary wood of both stem and root of that species ${ }^{2}$. He states that G. punctata, pannonica, and purpurea agree anatomically with G. lutea.

In G. cruciata, Jost ${ }^{8}$ found phloëm-strands in the secondary wood of the stem, but not of the root. Weiss also found interxylary phloëm in the fleshy roots of some Gentianeae ${ }^{4}$. It is evident that the anatomy of the order will repay further investigation, especially as regards the relation between stemand root-structure.

We examined a considerable number of other roots of plants with bicollateral bundles, but the results do not call for

A. Meyer, Beiträge zar Kenntniss pharmaceutisch wichtiger Gewächse, V. Ueber Gentiana lutea, \&c. Archiv für Pharmacie, 3te Reihe, Bd. XXI. 1883 .

Loc. cit, pp. 502, 56.9.

L. Jost, Die Zerklüftungen einiger Rhizome and Warzeln ; Bot. Zeitung, I 89o, p. $44^{2}$.

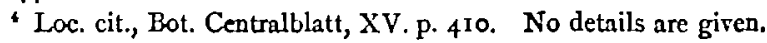




\section{Scott and Brebner.-On Internal Phloëm}

detailed description. In Oenothera longiflora, Jacq. we were able to confirm Weiss's observations as to the presence of centrifugally formed interxylary phloëm in the root of this genus ${ }^{1}$. A large amount of secondary phloëm-parenchyma is formed here, but the groups of sieve-tubes are small on both sides of the cambium.

In the following bicollateral plants the roots investigated showed external phloëm only :Myrtus mucronatus, Cambess. Lythrum Graefferi, Ten. Calystegia sepium ${ }^{8}, \mathrm{R} . \mathrm{Br} . \quad$ Apocynum cannabinum, L. Willughbeia flavescens, Dyer. Willughbeia firma, B1. Cryptostegiagrandiflora, R. Br. Dischidia nummularia, R. Br. Hoya pendula, Wight et Arn. Periploca graeca, L. Daplune Mezereum, L.

In all these cases it is probable that the transition from stem to root takes place as in Ipomoea and Browallia, and that the medullary phloëm of the stem is continuous with the external phloëm of the root.

Our conclusions as regards the roots may be summed up as follows :-

r. The majority of the plants examined with bicollateral bundles in the stem showed normal structure of the root, the medullary phloëm (to judge from the cases specially investigated) turning outwards in the hypocotyl with the protoxylemgroups. It is thus continuous with the external phloëm of the root-system.

2. A certain number of roots among the plants in question have interxylary strands of phloëm. These may be (a) primary, (b) secondary, or (c) tertiary. The first, as regards the main root, form the direct downward prolongation of the medullary phloëm of the stem, the phloëm-strands running down through the wood, instead of turning outwards to join the external phloëm. The secondary interxylary phloëm, which may be limited to the root or extend also into the stem, is in the plants here described formed centrifugally, on

1 Loc. cit, Flora, 1880.

${ }^{2}$ Cf. however the paper on Ipomoea versicolor, Scott, Ann. of Bot. No. XVIII. 


\section{in the Root and Stem of Dicotyledons. 283}

the inner side of the cambium. The tertiary strands are differentiated from the older secondary woody parenchyma,. when already remote from the cambium, and are especially characteristic of fleshy roots. Intraxylary (medullary) phloën has so far only been found in the roots of Strychnos and Clizronia.

\section{SPECIAL MOdifications IN THE STRUCTURE OF THE STEM.}

We are not aware that any cases have hitherto been recorded of the formation of medullary wood by an internal cambium in plants with undoubtedly bicollateral structure of the bundles. As was pointed out in the introduction, Weiss, in agreement with Vesque, has made the constant absence of medullary wood a criterion by which the internal phloëm of bicollateral bundles can be distinguished from that which belongs to an independent bundle-system in the pith (e.g. Tecoma). On this ground, among others, Weiss has removed the internal phloëm of certain Cichoriaceae, Campanulaceae, and Acanthaceae, from the former to the latter category $^{1}$. We have found, however, that in some plants with typical bicollateral structure a true internal cambium is active, producing new wood as well as new phloëm, the orientation of the two being inverted as compared with the normal parts of the bundle.

I. Apocynum cannabinum, L. The Apocynaceae are enumerated by Vesque, De Bary, Weiss, Solereder, \&c. among plants characterized by bicollateral structure of the bundles, and the character is here of ordinal value. The above species (the so-called 'Indian Hemp') is thoroughly typical in this respect. The internal phloëm is developed from the procambium simultaneously with the xylem and external phloëm, and from the first exceeds the latter in extent. It lies close to the protoxylem-groups of the bundles, only one or two

\footnotetext{
${ }^{1}$ Loc. cit., Bot. Centralblatt, XV. Pp. 32 I, 396, \&c.
} 


\section{Scott and Brebner.-On Internal Phloëm}

parenchymatous cells intervening between the primitive tracheae and the nearest internal sieve-tubes. It is not until the stem has attained a considerable thickness that any departure from ordinary bicollateral structure begins. At the stage shown in Fig. I3, the normal wood has a radial thickness of from seventy to ninety elements. The very characteristic internal phloëm forms a ring, which is not however continuous but is broken up into groups by narrow radial strands of parenchyma from one to three cells wide. Often, but not always, these rays correspond to the primary medullary rays of the normal wood. Not only is the internal greater in amount than the external phloëm, but its individual elements are also larger. The internal sieve-tubes often reach $.03 \mathrm{~mm}$. in diameter, while the normal ones scarcely exceed $.02 \mathrm{~mm}$. In some places an internal cambium has appeared, which at one or two points, opposite the protoxylem of the larger bundles, has begun to form tissue on its outer side. This tissue is the internal centripetal wood. The cambial divisions begin in the parenchymatous cells immediately bordering on the outer edge of the phloëm. Thus the internal is separated from the normal wood by one or two layers of thin-walled cells. The first xylem-elements formed are lignified parenchyma.

The internal cambium soon extends all round the pith, but its production of wood is for a long time limited to the regions where it first started. Elsewhere its activity is limited to the formation of additional phloëm on its inner face. When the normal wood is from 130 to 150 cells in radial thickness the internal woody masses are about fifteen cells thick (Fig. I4).

At a still later stage the internal wood becomes much more extensive. In the oldest stem at our disposal, about $\mathrm{I}_{4} 4 \mathrm{~cm}$. in diameter, it forms eight masses, which together occupy the greater part of the circumference of the pith. These masses lie opposite those parts of the normal wood which are richest in vessels, or, in other words, the internal wood still shows a relation to the primary bundles. Its maximum thickness now 
amounts to twenty-five elements, equal to about one-eighth of the normal wood. The internal cambium forms most phloem where it does not produce any wood. Opposite the woody groups the number of phloëm-elements is smaller and they also undergo greater compression (see Fig. 14).

The internal centripetal wood, where it is well developed, consists of elements of three kinds: (I) fibrous cells with pointed ends which form the small lumina seen between the larger elements in transverse sections (Fig. J4); (2) xylemparenchyma, and (3) ray-parenchyma. The internal xylemrays resemble those of the normal wood, but their cells are less elongated radially. All the elements have lignified walls, and simple elliptical pits, which in the fibrous cells are spirally arranged. The internal wood chiefly differs from the external in the absence of vessels.

It may be added that the internal sieve-tubes are of perfectly typical structure, with lateral sieve-fields as well as transverse plates, which form callus in autumn.

The pith is very lacunar and offers comparatively little resistance to the growth of the internal vascular tissues.

2. Willughbeia firma, Bl. (Apocynaceae). This climbing representative of the order shows the same structure as Apocynum cannabinum, namely centripetal internal wood, but in a still more striking form, for in Willughbeia the internal wood contains large vessels. Its development begins here even later than in Apocynzum. When the normal wood is on the average about eighty cells in radial thickness there is still no sign of internal xylem. The inner phloëm-groups form a ring, and are only separated from one another by narrow rays of parenchyma. There is already an active internal cambium which has arisen by division of about the third layer of parenchymatous cells within the protoxylem, and has added largely to the phloëm, so that the older phloëm-elements and some of the pith-cells also are becoming crushed and obliterated. The pith contains very large thick-walled sclerenchymatous fibres, and also large laticiferous cells. As the inward growth of the internal phloëm continues, the rays keep pace 
with it, chiefly by extension of their cells without division. The internal sieve-tubes are usually about $025 \mathrm{~mm}$. in diameter, and have very abundant proteid contents. Besides the typical phloëm-elements, the internal groups, like the pith, contain septate crystal-sacs, such as are also found in the normal external phloëm. The two phloëm-systems are about equal in extent. The internal ring has the advantage in radial thickness (which amounts to ten elements), but this is balanced by the greater periphery of the external phloëm.

In an older stem, in which the normal wood has about 140 elements on the radius, the centripetal xylem has appeared. It is formed in irregular groups, one of which is shown in Fig. 15. The elements of this internal wood are (I) vessels with bordered pits, composed of long joints, and reaching $\cdot 04 \mathrm{~mm}$. in diameter (about half that of the largest vessels of the normal wood); (2) xylem-parenchyma, and (3) radially elongated cells which may be regarded as forming xylem-rays. The centripetal wood, which is entirely produced by the internal cambium, is therefore of perfectly typical structure. The parenchyma, lying between the outer margin of the centripetal wood and the protoxylem, becomes partially lignified. In one case we found reticulated elements, probably vessels, in this position.

In the older stems the greater development of the internal vascular tissues has necessarily produced increased obliteration towards the pith. Many of the older sieve-tubes have very callous plates.

3. Periploca graeca, L. (Asclepiadeae). In this plant there is a very distinct internal cambium, which produces a large amount of secondary phloëm towards the pith. It also occasionally forms a few lignified elements in centripetal direction, but in the stems investigated the amount of internal wood was insignificant.

The cases of Apocynum and Willughbeia are sufficient to invalidate the generalization of Vesque and Weiss that the inner cambium of bicollateral bundles is a 'false' cambium 
capable of producing phloëm only without wood. All such arbitrary limitations of the possibilities of dicotyledonous: structure are rash. Until Sanio's discovery in Tecoma, no, one would have suspected the existence of medullary cambium at all. Now we know that it is of common occurrence, and that whether it be connected with bicollateral or with independent medullary bundles, it is alike able to form xylem or phloëm or both, according to the special requirements of the. plant. The only safe generalization as to cambium is that it. may arise in any living tissue, to whatever 'system' this may belong, and that it is capable of producing any form of tissue. for which at the moment the plant has an increased demand.

4. Gentiana acaulis, L. Our observations on this plant, to. which reference has already been made, may be described very shortly, for they are in close agreement with those of Meyer and Jost, above cited, on other species of the genus. In the stem of this species the bulk of the phloëm is internal. Its arrangement is unusually complex. In the older inter-. nodes we find two concentric rings of internal phloëm-groups, in addition to which there is often a third set lying quite in the middle of the pith. At first sight one is disposed to regard these strands as forming an independent medullary system, but investigation of their longitudinal course shows that this is not so, but that all the internal strands are branches from the inner phloëm of the bicollateral bundles, so. even in this extreme case we see no sufficient ground for. departing from De Bary's terminology.

The main bundles of the leaf are bicollateral. The leaves themselves are opposite, decussate, and sheathing. Three. bundles enter the stem from each leaf, but fuse into one broad bundle before turning down into the internode. The fused bundle runs down through two internodes, its elements spreading themselves out tangentially ${ }^{1}$, and ultimately joins the. outgoing bundles of the leaf vertically beneath, i. e. at the.

1 As Meyer says of G. lutea, the elements separate so widely that one can no longer speak of the course of the bundles, but only of the connection of the elements; loc. cit., p. 5 or. 


\section{Scott and Brebner.-On Internal Phlö̈m}

second node below. The internal phloëm accompanies the leaf-trace bundles into the stem, and runs straight down through two internodes, where it joins that of the next bundle vertically beneath. It is usually at this point that branches arise which penetrate somewhat more deeply into the pith, while those which reach the middle of the stem are given off lower down still. Hence as a rule the transverse section of the youngest internodes shows a single ring of internal phloëm-groups, a rather older part has a double ring, while the more central groups arise by the division of pith-cells at a comparatively late stage. But there is no great constancy about this and occasionally the more internal branches arise much earlier. The different strands are further connected by anastomoses ${ }^{1}$. We may add that sometimes phloëm-groups are formed outside the protoxylem elements, between these and the rest of the wood. This is an approach to the formation of interxylary phloëm-islands, as in some other Gentians, Chironia, \&c.

We have described the distribution of the phloëm in this plant because it shows an extreme modification of ordinary bicollateral structure, and yet is readily referable to the type. It may be added that the external phloëm-groups are also very scattered and widely separated from the xylem, so that there is a certain analogy between the two systems as regards distribution. We pass over our other observations on plants with strictly bicollateral bundles, as they present no new points of importance, and go on to a plant the remarkable structure of which is only indirectly connected with our main subject.

5. Acantholimon glumaceum, Boiss. (Plumbagineae). The anatomy of this genus has already been the subject of several investigations, the earliest of which is due to Prof. Oliver ${ }^{2}$, who especially insists upon the absence of typical medullary rays. $\mathrm{He}$ also observed and figured among other peculiarities the

1 Cf. Meyer, loc. cit., p. इ01 ; and Jost, loc. cit., p. 439.

$2 D$. Oliver, On the structure of the stem in certain species of Caryophylleac and Plumbagineae; Trans. Linnean Soc. vol. XXII, I859. 
occurrence of concentric belts of parenchyma in the wood. Krüger ${ }^{1}$ confirmed Prof. Oliver's results as to the medullary rays and was the first to discover concentric bands of typical phloëm in the wood. This remarkable anomaly he was inclined to refer to the action of successively renewed cambial layers. Lastly, Solereder ${ }^{2}$ confirmed Krüger's discovery, and found, in the occurrence of tangential divisions between the xylem and interxylary phloëm-zones, a clear proof that the wood as a whole (Holzkörper) owes its origin to the appearance of successive cambial layers. Both he and Krüger, however, recognise the possibility that the interxylary phloëm might arise as in Strychnos, i. e. as De Bary erroneously supposed to be the case in Strychnos. On this view the interxylary phloëm would be formed centrifugally on the inner side of the cambium. We proved in our former paper ${ }^{3}$ that the phloëm in the wood of Strychnos is developed centripetally, and it was the apparent analogy of structure between that genus and Acantholimon, which led us to examine the latter. Some divergences in detail, between our observations and those of previous writers, may well be due to specific differences.

Acantholimon glumaceum is well known in gardens as a rock-plant. Its habit is not unlike that of its British relation, Armeria vulgaris. The latter, however, does not share its anomalies of structure.

The diagrammatic transverse section (Fig. 16) will give a sufficient idea of the extraordinary structure of a thick stem. In order to understand the complicated conditions at maturity, it will be necessary to trace the development.

The young stem has a perfectly normal structure. The bundle-ring is interrupted by several (usually $3-5$ ) broad radial strands of parenchyma. The tangential section shows that each of these rays occurs immediately above the exit of a leaf-trace bundle. We do not see that they differ essentially from the primary medullary rays of other stems, which in all cases are

1 Otto Krüger, Beitrag zur Kenntniss der sogenannten anomalen Holzbildungen. Dissertation. Leipzig, 1884 .

Loc cit, Holzstructar, p. $16_{4}$

- Anuals of Botany, vol. III. 


\section{Scolt and Brebner.-On Intsrnal Phlö̈m}

the spaces (filled with parenchyma) between the bundles, and must therefore have a definite relation to the bundle-system. In this plant, and in many others, the outgoing bundle leaves, as it were, a parenchymatous space above its exit, which is only closed over further up by the converging bundles on either side. This space is the primary ray. In Acantholinon there is no interfascicular cambium, the ray following the growth in thickness by extension of its cells, perhaps accompanied by a few irregular divisions. No secondary rays are formed at any stage which has come under our observation.

A normal fascicular cambium is formed between xylem and phloëm and for some time the thickening goes on in a perfectly typical way. The annular and spiral vessels of the primary wood are succeeded by a secondary xylem, which is especially rich in vessels. These are of two kinds: large vessels with bordered pits, and much smaller ones with a conspicuous spiral thickening and small pits between the coils. The closely packed elements with lignified thickened walls, which in a transverse section might easily be taken for woody parenchyma, are in reality these small vessels. The parenchyma, which is scattered among them, is entirely thinwalled and usually unlignified. In addition to these elements, the secondary wood contains scattered strands of fibres thickened so that the cavity has all but disappeared. The larger vessels occur in rather regular concentric layers. The phloëm is very thick. It consists of elongated cells equivalent to phloëm-parenchyma, but prosenchymatous in shape, of sieve-tubes, with inclined terminal sieve-plates, and their companion-cells. The first anomalous formations generally appear in stems about $2 \mathrm{~mm}$. in diameter, where there is a wide zone of secondary wood and the outer cortex has been already cast off by periderm. The first departure from normal structure consists in the appearance of an internal cambium. This has not hitherto been observed. The cambial divisions may occur immediately within the protoxylem of the bundles in the outermost small-celled tissues of the pith, but in other 


\section{in the Root and Stem of Dicotyledoins.}

cases they occur in the parenchyma of the bundles themselves outside the protoxylem, so that the latter is cut off from the body of the wood ${ }^{1}$. The internal cambium at once begins to form centripetal wood on its outer surface and internal phloëm towards the pith. If the cambium has cut off the protoxylem the latter is necessarily carried inwards towards the centre of the pith in front of the advancing phloëm. Figs. I7 and 18 show the more normal type, where the cambium arises within the protoxylem. The difference is of no importance whatever, as regards the final result. The medullary formations are localized opposite the bundles; sometimes there is one internal strand to each bundle, sometimes there are two. Both internal wood and phloëm agree exactly in structure with the normal tissues. In the former, the relatively large vessels are conspicuous. The secondary formations encroach very seriously on the pith. We have found the internal wood as much as twenty-five elements in radial thickness; the phloëm is generally less extensive. It is quite possible that the internal cambium may at first be continuous with the normal cambium at the nodes, as Robinson found to be the case in Iodes tomentella ${ }^{2}$, but we have no proof of this. The formations in Acantholimon bear a close resemblance to those observed by Robinson. The similarity with Tecoma is more superficial, for in this latter plant a medullary phloëm-strand is present before the cambium appears, which is not the case here. In Acantholimon the internal wood and phloëm are entirely secondary, and it would be a forced view to regard them as forming part of the leaf-trace system. The curious structure described by Dangeard (l.c.) in Acanthophyllum has some analogy, but differs in the fact that the cambium completely surrounds the wedges of wood, which we have never found in Acantholimon. We suspeçt that the anomaly discovered by Morot in the Basellaceae is more nearly related to the present case than to ordinary bicollateral structure.

1 This process is comparable mutatis mutandis to the mode of origin of the normal cambium in the root of Chironia.

${ }^{2}$ Lac. cit. 


\section{Scott and Brebner.-On Internal Phloëm}

In the mean time other anomalies have made their appearance. At a certain point in the development, in some cases, when the normal wood has only twelve cells on the radius, in others, when it has formed from thirty to forty layers, interxylary phloëm appears. In one specially instructive case the thickening was very eccentric: on one side the wood and bast were normal, on the other side the wood was much thicker and traversed by two tangential bands of interxylary phloëm, each of which had a cambium on its inner side (cf. Fig. 19). In this stem, the first interxylary cambium of the anomalous part exactly fitted on to the external cambium of the normal portion. We call attention to this exceptional case, because it throws light on the origin of the concentric zones. As a rule, the thickening is approximately uniform round the whole circumference. The bands of interxylary cambium and phloëm sometimes run completely round the stem interrupted only by the parenchymatous rays. But more often their arrangement is less regular, the number of concentric bands varying not only in the different woody wedges, but also within the same wedge. The general arrangement of the tissues is such, that the inner layer of each concentric zone of xylem contains the larger vessels. Its outer portion is formed of the densely packed smaller vessels with thin-walled parenchyma interspersed (Fig. 19). The wider phloëm-zones have precisely the same structure as the normal external phloëm (Fig. 20). The sieve-plates in autumn are often callous. The narrower zones of thin-walled tissue are occasionally destitute of sieve-tubes, consisting only of cambium on the inner and thin-walled phloëm-parenchyma on the outer side. But this is exceptional and, as a rule, the interxylary zones consist of typical phloëm. The interxylary cambium which always lies on the inner side of the phloëm band, does not appear to be very active, for no crushing to speak of takes place. The radial rows of the interxylary phloëm are continuous inwards (through the cambium), but not outwards, with those of the wood. There can be no doubt that the development of these phloëm-bands is centri- 
petal (cf. Figs. I9 and 20). The only satisfactory explanation of the whole structure is that we have here to do with successive layers of extrafascicular cambium. For a time the normal cambium continues its activity as in ordinary Dicotyledons. Then a new cambial layer is formed by division of the cells of the pericycle or of the outer phloëm-parenchyma. This layer may be continuous (except in the rays) all round the stem, or it may be partial, abutting at either end on the normal cambium. The new layer forms wood internally and phloëm externally, so that the original cambium and phloëm become enclosed, and so the first interxylary zone is formed. After an interval the process is repeated. The first extrafascicular cambium is replaced by a more external layer, and so another complete or partial phloëm zone is left behind and becomes imbedded in the wood. This process may take place over and over again, until we have the complicated structure of an old stem, as shown in the diagram (Fig. I6). As we have already seen, each enclosed cambium retains something of its activity and does not itself pass over into permanent tissue.

These are conclusions, which we have drawn from the careful comparison of many stems, but we have not yet been so fortunate as to observe the first origin of a new cambial layer. Possibly the first extrafascicular cambium may arise in the pericycle, certainly the later ones are formed from the phloëm-parenchyma. In the exceptional cases, when the interxylary zones have no sieve-tubes, we may assume that this new cambium arose very near the old, so that the differentiation of the products of the latter remained incomplete.

Occasionally small round bundles are seen in transverse sections imbedded in the wood, just outside an interxylary zone. These are leaf-trace bundles on their very oblique outward course, which have become enclosed by extrafascicular cambium.

The adventitious roots have a normal structure.

Our conclusions as to Acantholimon are as follows :-

I. An internal cambium is formed at a late stage, either 


\section{.294 Scott and Brebner.-On Internal Phloèm}

just inside or just outside the protoxylem. It produces a large amount of medullary wood and phloëm, with inverted orientation.

2. The concentric bands of phloëm and xylem, of which the secondary tissues are composed, are due to the activity of successive cambial layers, as was conjectured by Krüger and Solereder.

\section{CONCLUSION.}

In concluding we wish to point out the bearing of our subject on a theory which has been recently put forward as to the function of the phloëm in general.

In opposition to the prevailing view that the phloëm is primarily the conducting tissue for the nitrogenous, and especially for the proteid, food-substances of the plant, Prof. Frank ${ }^{1}$ and Dr. Blass ${ }^{2}$ maintain that the phloëm is essentially a store-tissue for the benefit of the wood. Prof. Frank says ${ }^{3}$ : 'The position which this tissue invariably occupies speaks most clearly for its function as a store-chamber of those substances which the cambial layer requires for the formation of the wood; for in all fibrovascular strands it is a faithful companion of the woody bundles, and it increases and diminishes in amount with the bulk of the woody bundle which is to be formed; it is constantly situated immediately outside the cambial layer; it forms an annular zone around the cambial ring where the latter surrounds a closed cylinder of wood, as in most dicotyledonous stems and trunks; it forms an isolated strand, placed exactly in front of the woody bundle with its cambium, when we have to do with isolated fibrovascular-strands, as is especially the case in the petioles and ribs of the leaf.' Dr. Blass, who worked in conjunction with Prof. Frank, expresses his views as follows: 'Just as the contents of the starch-sheath serve to build up the bast-cells,

1 Lehrbach der Pflanzenphysiologie, I 890.

2 Untersuchungen über die physiologische Bedentung des Siebtheils der Gefässbündel ; Pringsheim's Jahrbücher, Bd. XXII, I 890 .

' Loc. cit., p. 162. 
so the contents of the phloëm are chiefly conveyed to the cambium in order to be employed in the activity of this meristematic zone and in the building up of the xylem ${ }^{1}$.' As evidence for this view, Dr. Blass, who has worked out the theory in detail, brings forward the facts that in trees the sievetubes nearest the cambium are richest in proteid contents; that in some cases the contents of the phloëm accumulate in autumn and are diminished when growth is renewed in the spring; that in some plants with reduced xylem (Drosera and certain aquatics) the sieve-tubes are rudimentary, containing nuclei and even chlorophyll-granules; and lastly that in the ringing experiments so often quoted in support of the prevailing views, the excessive growth above the incision is due simply to the formation of 'wound-parenchyma,' and not to the interruption of the downward current of food-material. In support of this contention, Dr. Blass states that the phloëm below the wound shows no diminution of its contents.

We purposely avoid criticising Dr. Blass's arguments, though it appears to us that his results are not inconsistent with the theory of conduction and in some points even lend it additional support. We willingly admit that in all plants with cambial growth the supply of food-materials for such growth must be an important function of the phloëm. Nor are we.aware that this has ever been denied. But we wish to point out that the anatomical relations of the phloëm are often quite inconsistent with the supposition that its exclusive or principal function is connected with the formation of wood.

In all the numerous plants which have bicollateral bundles or an analogous arrangement of tissues, a great part of the phloëm, often the greater part and sometimes nearly the whole, is placed in that region of the stem where no formation of wood is going on, in a position as remote as possible from the wood-producing cambium, for the rare exceptions in which some internal wood is also formed may here be left out of consideration. Yet this internal phloem is absolutely

1 Loc. cit., p. 258. 


\section{Scott and Brebner.-On Internal Phloëm}

typical in structure and contents. Nor is it a merely transitory tissue. Long after it is cut off from the normal cambium by a broad zone of secondary wood, it goes on increasing, often to a much greater extent than the normal external phloëm. In many of these plants it is the latter, the phloëm in contact with the wood-producing cambium, which is tending to become rudimentary, while the internal phloëm, remote from the cambium, is abundantly developed and retains all its typical characters.

That the internal, like any other phloëm, indirectly supplies the cambium as well as other growing regions, we do not for a moment doubt, but this is simply to say that it is a conducting tissue.

So too with the 'phloëm-islands.' In plants like Strychnos or Salvadora these are no sooner formed than they become imbedded in the dense wood, and are cut off from all direct communication with the cambium. It would be easy to cite other examples, as the stem of the Chenopodiaceae and many allied orders, in which almost all the phloëm is deeply imbedded in the fully formed wood, or the Monocotyledons generally, where the closed bundles retain a typical and active phloëm for months or years after all formation of wood has been completed.

In the light of facts such as these we cannot but think that the view of Prof. Frank and Dr. Blass depends on too one-sided a consideration of typical dicotyledonous anatomy. The passage quoted above from the former author, as well as Dr. Blass's concluding statement that 'a typical condition of the sieve-tubes is only to be found where wood-elements are to be formed ',' seem to us not to be justified by facts. Our results as to the continuity of the various phloëm-systems in root and stem tend to give further anatomical support to the theory of the conducting functions of this tissue, a theory which, as we need hardly point out, is fully consistent with the view of Prof. Sachs that the phloëm may also be the seat of proteid-formation. 
We are indebted for our material partly to the Director of the Royal Gardens, Kew, partly to Mr. H. N. Ridley, of the Botanic Gardens, Singapore, who has been so kind as to send us a number of specimens carefully preserved in spirit.

We have further to thank the officers of the botanical department of the British Museum, and also Mr. B. Daydon Jackson, Sec. L. S., for their kind help in the nomenclature of species.

\section{POSTSCRIPT.}

When this paper was completed in December, 1890 , we had not seen the work of M. Lamonnette, 'Recherches sur l'origine morphologique da liber interne,' which appeared in Norember, in the Annales des Sci. Nat., Bot. Sér. 7. T. XI.

M. Lamounette has made a number of valuable observations on the origin of internal phloëm in the hypocotyl, the cotyledons, the terminal bad of the stem, and the leaves. He strongly supports the views of M. Hérail, and rejects the term 'bicollaterality' in all cases, even in the Cucurbitaceae (p. 264). He regards the internal phloëm as being due to an ulterior evolntion of the medallary cells, analogous to the formation of periderm in the cortex (p. 235), and considers that it was primarily independent of the normal bundles, its close association with them in the Cucurbitaceae not having been attained at a later phylogenetic stage. His view of the internal phloëm as an 'acquired character' which has become hereditary (p. 278 ) is evidently beyond criticism in the present state of our knowledge.

As regards the transition from stem to root, M. Lamounette says that the internal phloëm, when present in the hypocotyl, is altogether formed in the medallary parenchyma, and not in any degree at the expense of the phloëm of the root (p. 277). He appears to attribute the opposite view to Gerard. Surely there is some confusion between course and development here. In the cases investigated by Gerrard and by ourselves there is no doubt as to the continuity between the internal phloëm of the hypocotyl and the external phloem of the root, but no one has ever supposed that the one is developed from the other. M. Lamounette appears to have overlooked this continuity in all cases, a fact which is probably explained by his having worked chiefly with very young seedlings. He rightly points out that the development of the internal phloem in the hypocotyl often takes place very late as is especially the case in Iporroed (p. 243). In the Onagraceae he finds that internal phloem is entirely absent from the hypocotyl, the cotyledons, and even the earlier-formed leaves (pp. 245 and 274). So far as the hypocotyl is concerned this can only be true of very young plants, for we know from Weiss's observations above cited that the internal phloem is here continued into the root, when it forms the innermost interrylary phloëm-strands (see above, p. 272). We suspect that in all cases continuity between the internal phloem of the stem and the phloëm of the root exists, though the connection may no doubt be established relatively late in some cases. 


\section{Scott and Brebner.-On Internal Phloëm}

M. Lamounette's careful observations on the origin of the internal phloëm in the growing point of the stem are of great interest. He finds that it always arises later than the normal tissues of the bundle, and that it is of medollary, not of procambial origin. The distinction in some cases is certainly a very fine one, and we have not always been able to detect it, bot we willingly accept M. Lamounette's results. We hope that our further investigations may throw additional light on this author's interesting hypothesis that the phylogenetic origin of all internal phloëm is to be traced to independent medullary gtrands, nnconnected with the normal bondlesystem.

Two other papers have lately appeared, bearing on our subject. Leonhard's Beiträge zur Anatomie der Apocyneen (Bot. Centralblatt, Bd. XLV, I89I) confirms the general occurrence of intemal phloëm throughout this order (with one doubtful cxception). The anthor appears to have fonnd phloëm embedded in the wood in Lyonsia, though his description is not perfectly clear, as he does not distinguish between interxylary and intraxylary phloëm.

Quite recently M. Hérail has published a preliminary note on mednllary. phloëm in the root (Comptes Rendus, April 13, I89I). He has discovered this structure in the adventitions roots of Vinca major and $V$. media, but not of $V$. minor, in which the pith soon becomes sclerotic. He points ont the necessary condition on which the occurrence of medullary phloëm in the root inanifestly depends; namely the presence of a permanently parenchymatous pith. He cites Van Tieghem's observation of internal phloëm in the root of Cucurbita, but is not acquainted with our description of this tissue in the root of Sirycknos, published in 1889. M. Hérail's observations are a welcome addition to our own.

May I, I89r.

D. H. S. \& G. B. 


\section{EXPLANATION OF FIGURES IN PLATES XVIII, $\mathrm{XIX}, \mathrm{XX}$.}

Illustrating Messrs. Scott and Brebner's paper on Internal Phloem.

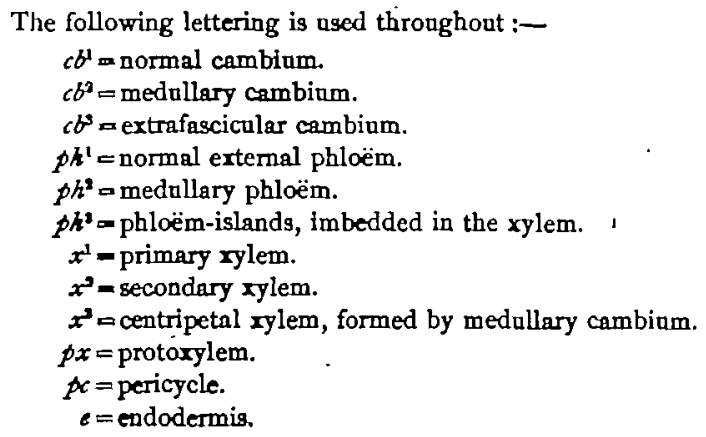

Figs. I-5, Browallia' viscosa.

The line $\mathrm{C}-\mathrm{C}^{1}$ is the plane of the cotyledons.

Fig. I. Transverse section of hypocotyl. Numerous groups of medullary phloèm. In this and the following figures the xylem of the cotyledonary traces is shaded dark. $\times 300$.

Fig. 2. Do. lower down. Three internal phloëm-groups are passing ont. $\times 300$.

Fig. 3. Do. still lower. Another phloëm-group is seen in the xylem on its way out. $\times 300$.

Fig. 4 Do. near root. Little medullary phloem is left. One group is seen passing out. $\times 300$.

Fig. 5. Transverse section of tap-root, showing typical diarch stracture. All the phloem is now united in the normal position. $\times 300$.

Fig. 6. Asclepias oblusifolia. Part of a transverse section from a thickened root. Two phloëm-islands shown imbedded in the xylem-parenchyma, near a group of ressels. $\times 150$.

Figs, $y$ and 8. Thladiantha dwbia.

Fig. 7. Semi-diagrammatic trangverse section of a root to show the distribution of the tissues. The protoxylem-groups coloured red, the rylem generally yellow, the sieve-tubes bluce, and the bast-fibres brown.

Fig. 8. Part of a transverse section from a similar root, showing a secondary ray in which interxylary phloëm has been formed. $\times 15^{\circ}$.

Figs. 9-1 2. Chironia peduncularis.

Fig. 9. Part of a transverse section of an octarch root, moderately thickened, to show general structure. $p h^{1}$ is here the approximately central group of medullary phloëm. Two protoxylem-elements are seen to the outside of the cambium. An intermediate one has become imbedded in the secondary wood. $\times 150$. 


\section{Scott and Brebur.-On Internal Phloèm, \&c.}

Fig. Io. Part of a transverse section of a young octarch root at the commencement of secondary thickening. The cambium is forming izside the isolated protoxylem-elements. Primary interrylary phloëm-groups are in course of development. $\times 300$.

Fig. II. Do. do. from a decarch root, at a stage very slightly later than Fig. Io. Four protoxylem-groups shown. To the left the cambial divisions take place inside the protorylem. The camblum passes outside the next two groups, and on the right divisions are seen on both sides of the protoxylem-element. This root had a considerable pith containing a large group of internal phloem. $\times 300$.

Fig. 12. Do. do. from a root at nearly the same stage as Fig. 9, showing the centrifugal development of the phloèm-islands on the inner side of the cambium. $\times 300$.

Figs. 13 and 14. Apocynum canmabinum.

Fig. I3. Part of a transverse section of a stem in which the normal wood is 70-90 cells thick. The development of centripetal wood from the internal cambium has just begun. It is separated from the protoxylem of one of the primary bundles by one or two layers of parenchyma $\times$ i 70 .

Fig. I4. Similar section from an older stem. The internal wood is now about I 5 cells thick. The internal phloëm projects far into the pith. $\times$ I 70 .

Fig. I5. Willaghbeia firma.

Part of a transverse section from a thick stem, showing the centripetal wood and internal cambium and phloẹm, and their relation to the protorylem of the normal wood. $\times 300$.

Figs. 16-20. Acantholimon glumaceum.

Fig. I6. Semi-diagrammatic transverse section of an old stem, to show the distribution of the tissues. Red $=$ protoxylem. Yellow $=$ xylem generally. Bluc - phloëm. The cortex, rays, and pith are left white.

Fig. I7. Part of a transverse section showing the inner part of the normal wood, the centripetal wood, and the internal cambium and phloëm. The centripetal wood is alone shaded. $\times 300$.

Fig. 18. Longitudinal section of the same. Notice specially the loosely coiled spirals of the protoxylem-vessels, on the inner side of which the centripetal wood is forming. Some of the internal sieve-tubes have callous plates. $\times 300$.

Fig. 19. Transwerse section showing part of an interxylary band of cambinm and phloëm. The cambiam lies on the irner side of the phloëm. $\times 300$. The external zone of wood $\left(x^{2} a\right)$ begins with large vessels.

Fig. 20. Longitudinal section of the same. The callous plates of the older interxylary sieve-tubes are shown. The outer part of the inner zone of wood $\left(x^{2}\right)$ consists chiefly of narrow spirally thickened vessels, while the inner part of the outer zone $\left(x^{3} a\right)$ has large pitted vessels. $\times 300$.

All the figures were drawn ander the camera lucida. Those $\times 300$ were drawn with a power of $45^{\circ}$ diam, and subsequently redaced to two-thirds. 
Annals of Botany

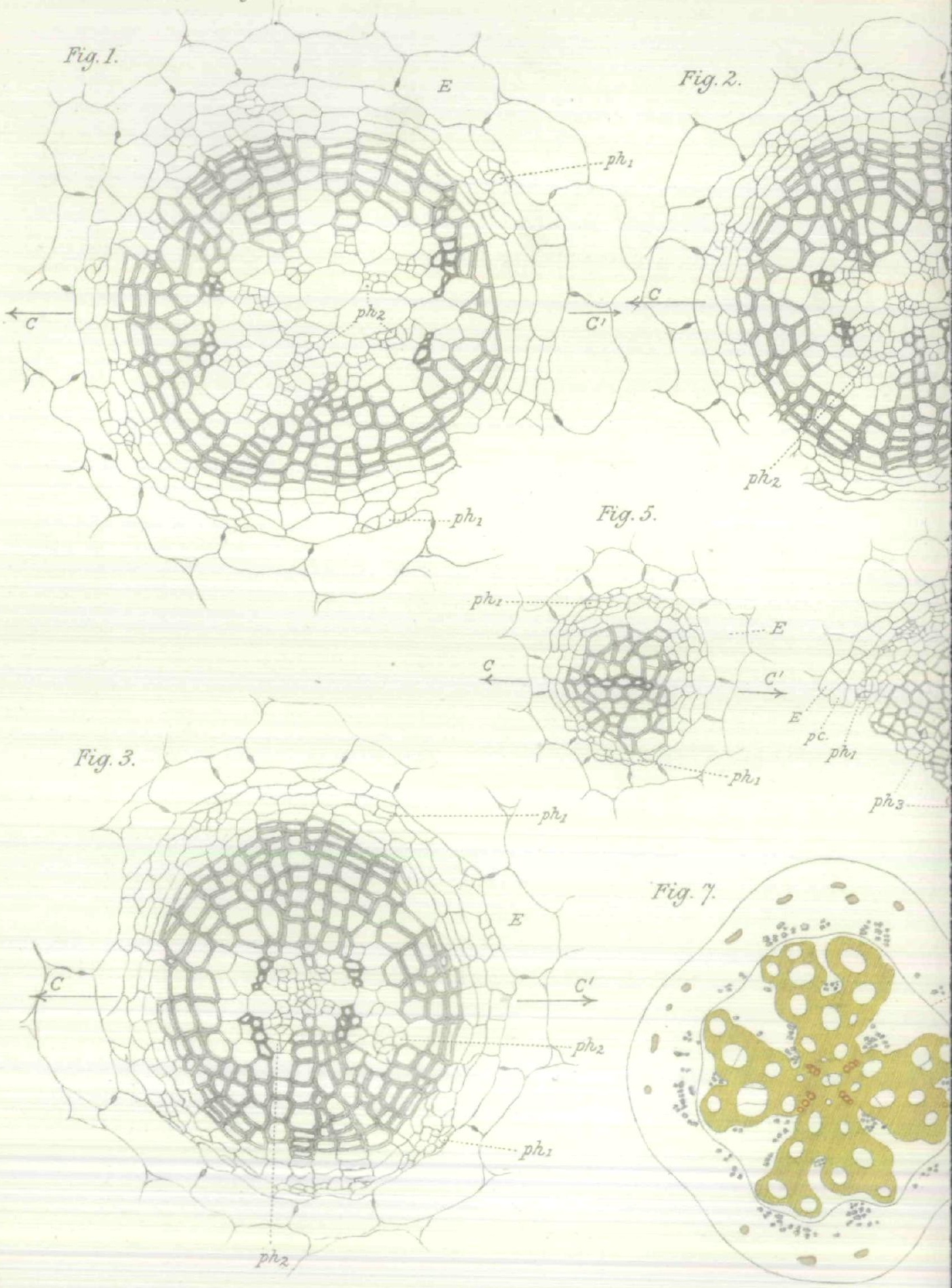




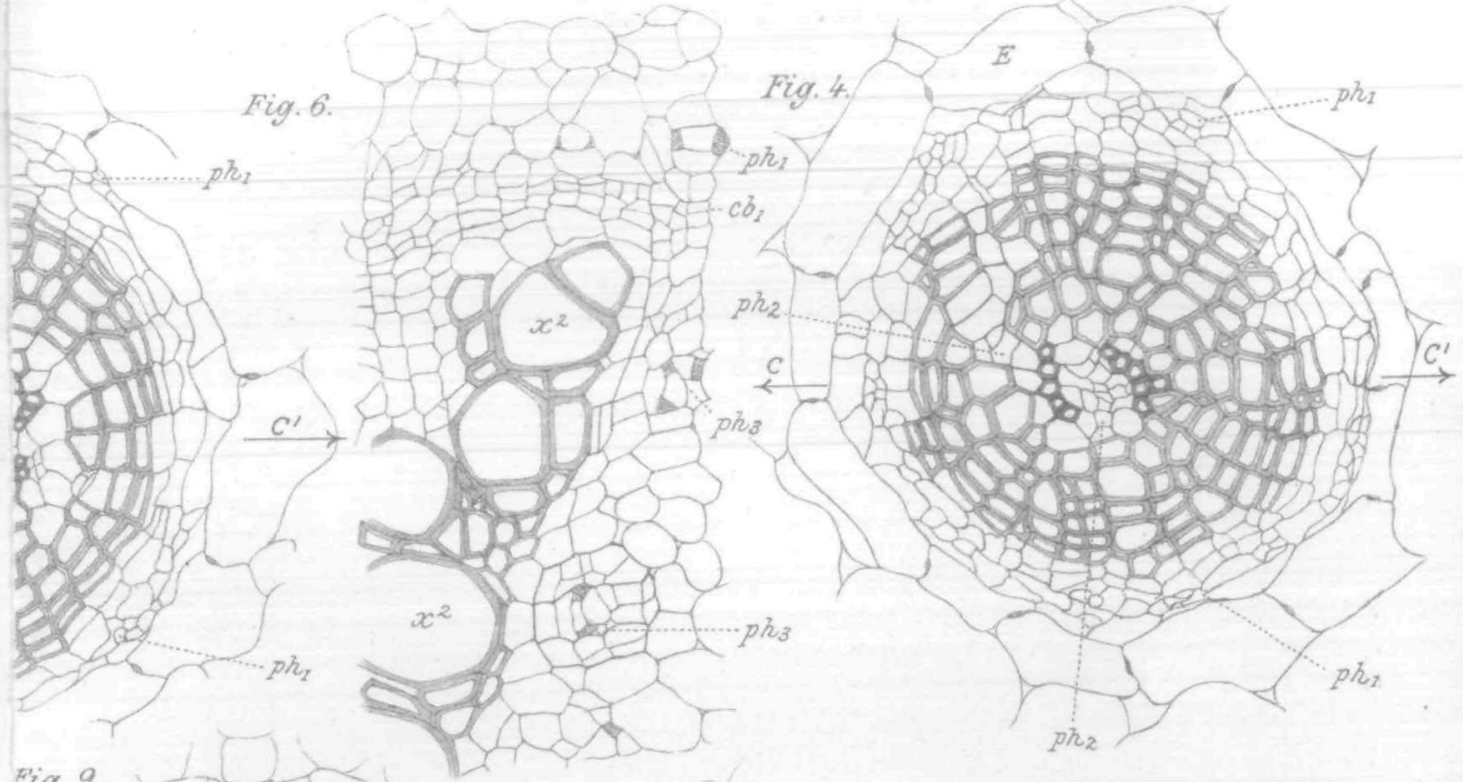

Fig. 9.

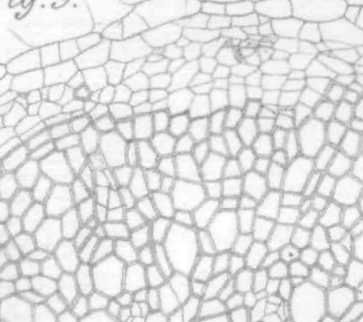

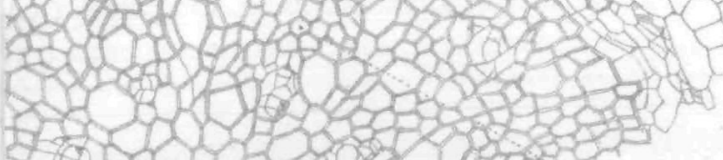

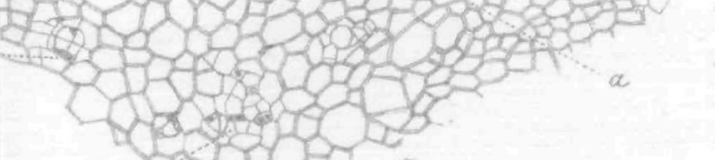

tantaly 3 .

phi Dogn? Fig.10.

Fig. 8.
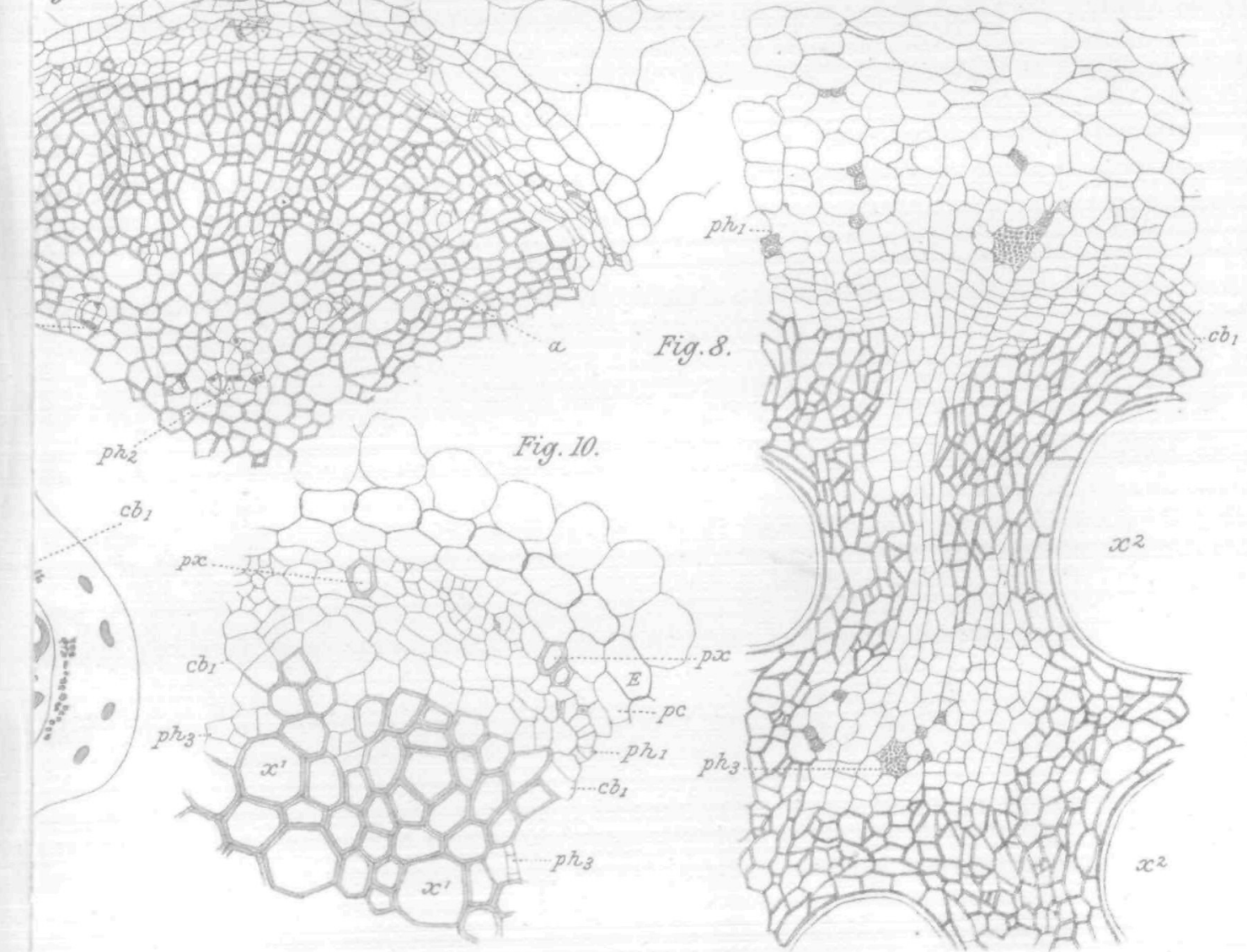

University Press, Oxford. 



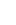




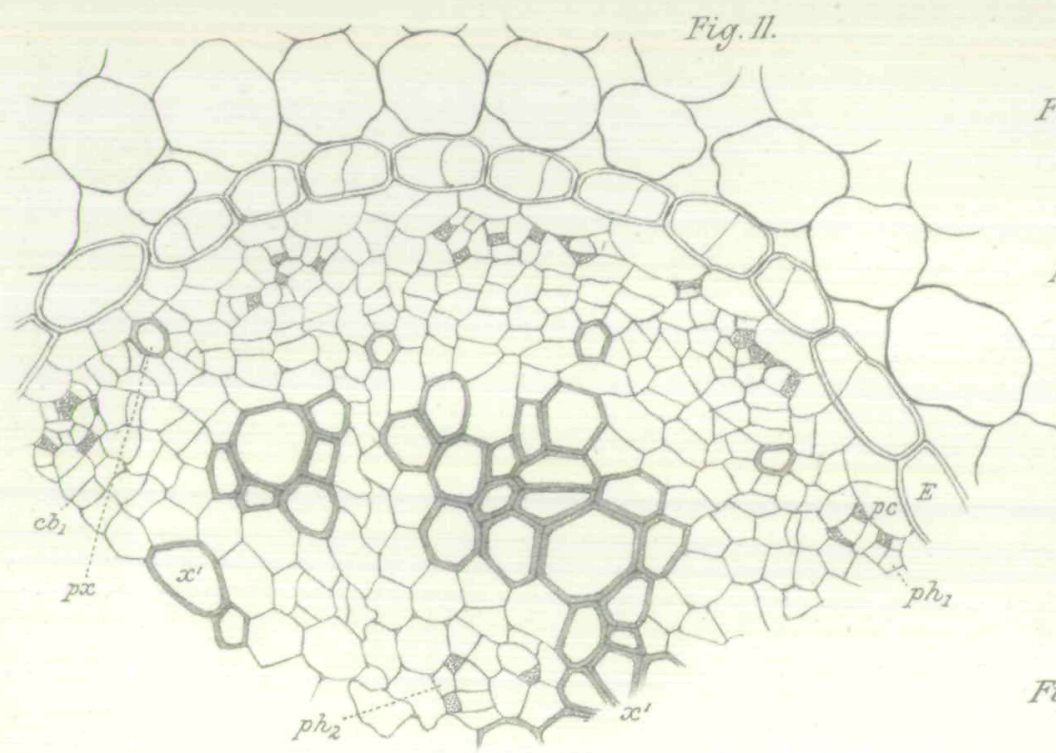

Fig. 12 .

Fig. 13 .
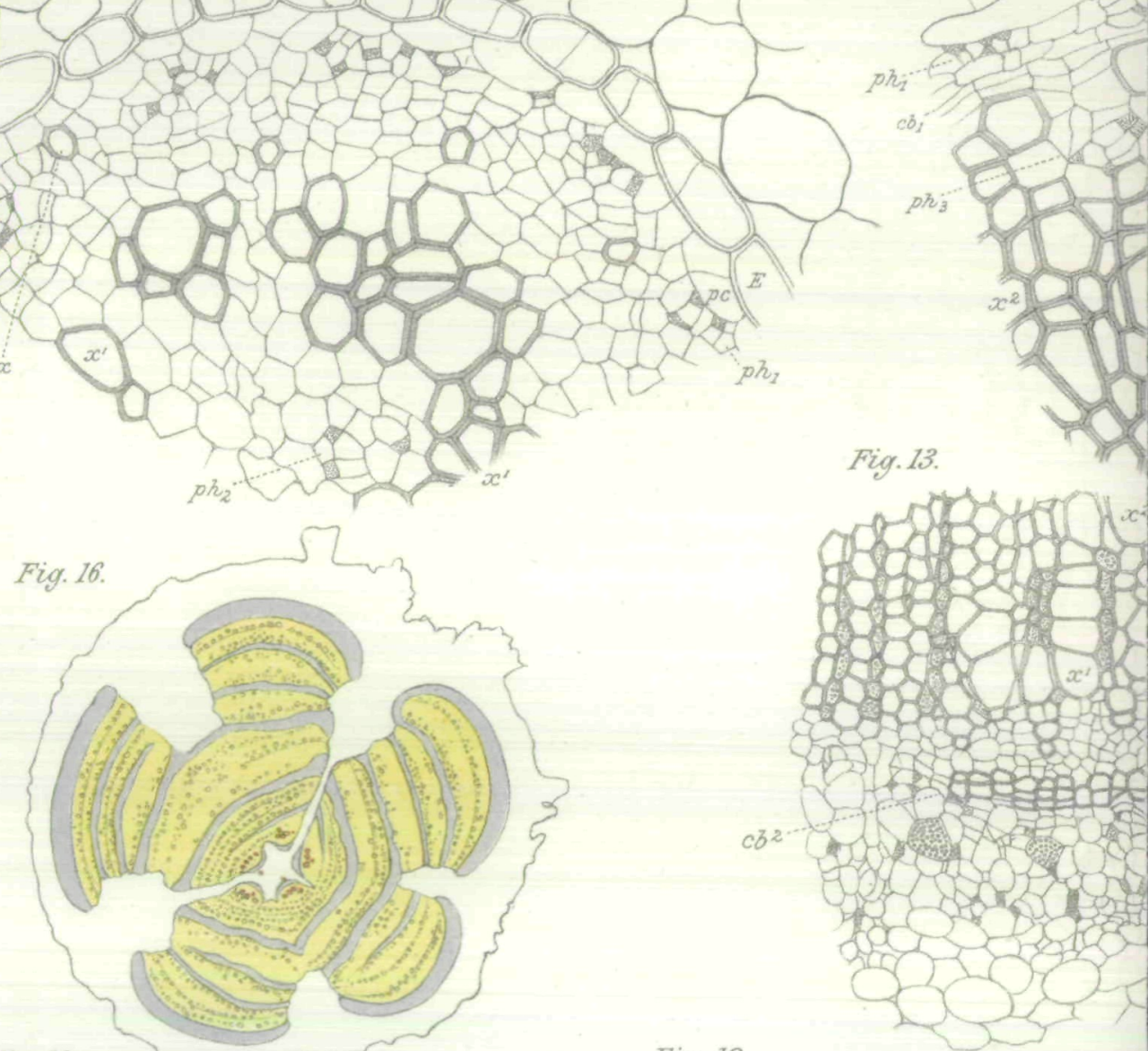

Fig. 15 .

Fig. 18.
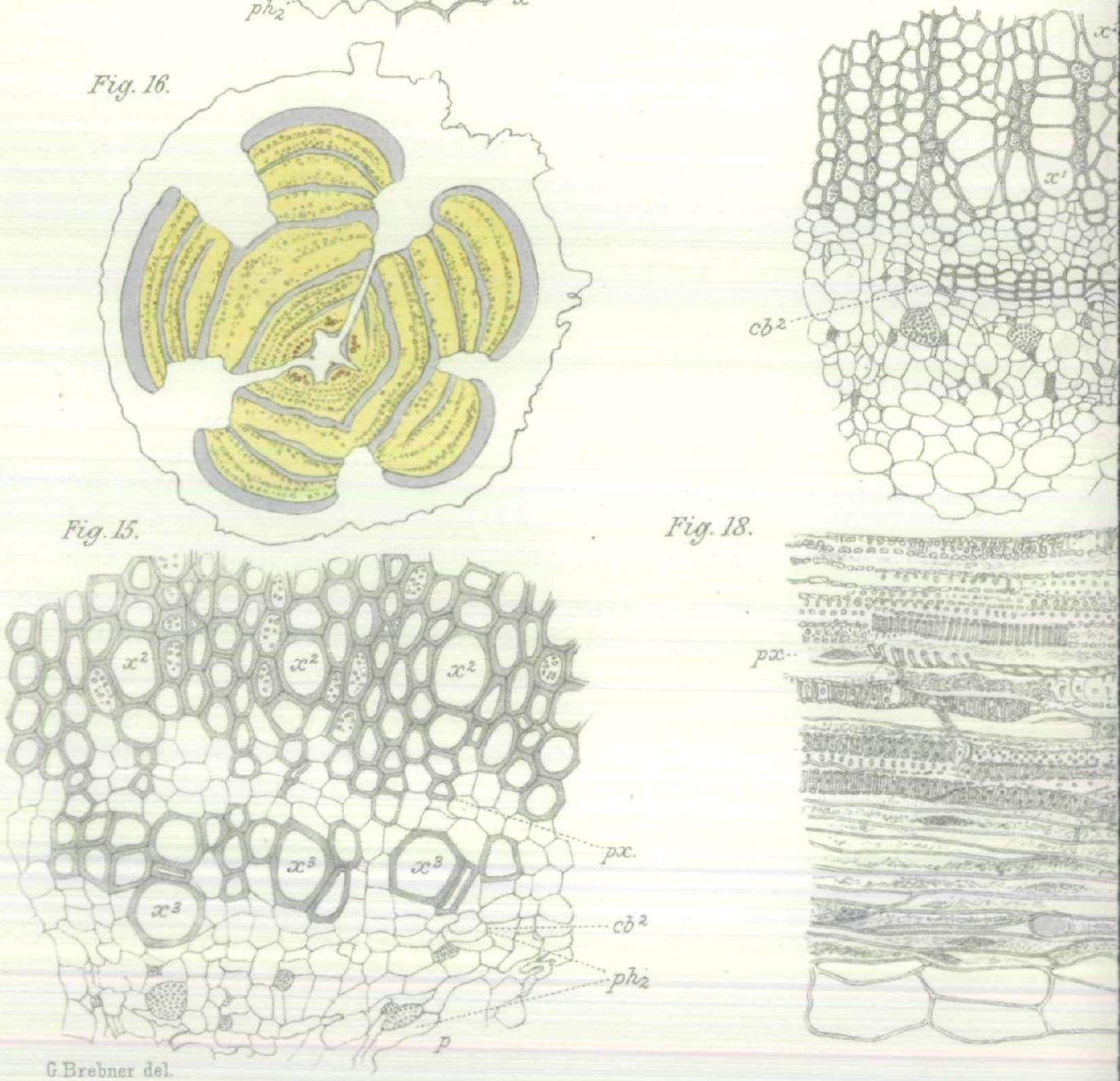

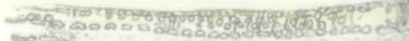

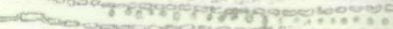
7.984.

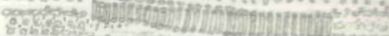
$p x-20$ smoens

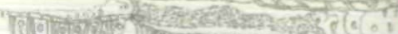

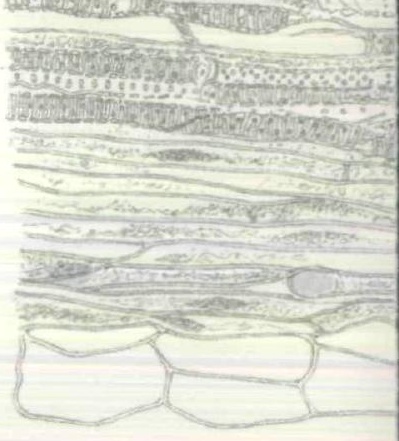
SCOTT \& BREBNER. - ON INTERNAL PHLOEM. 

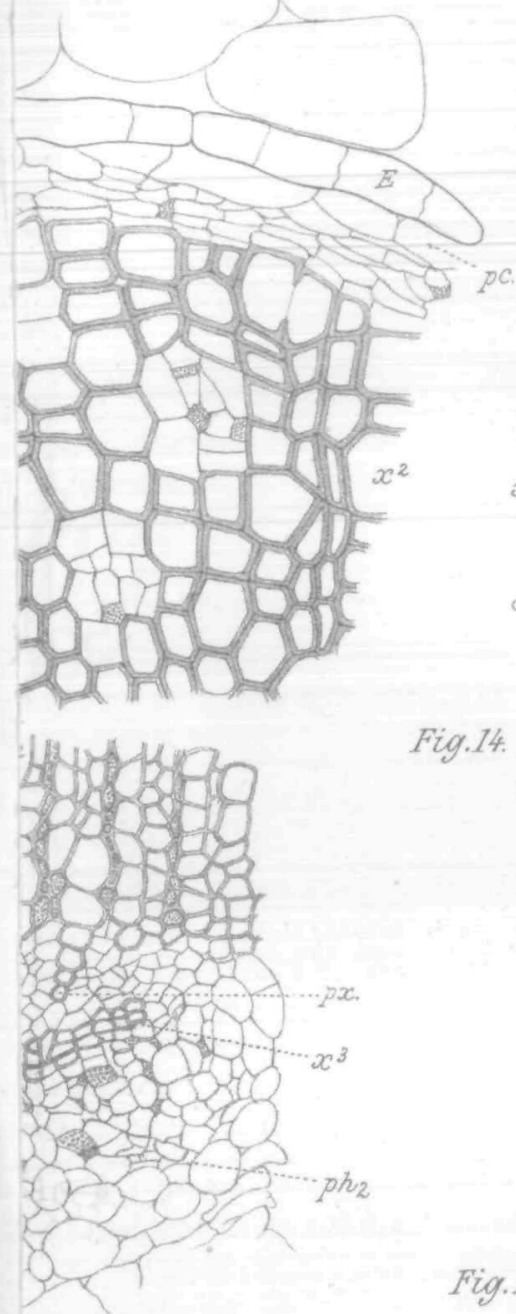

Fig.14.

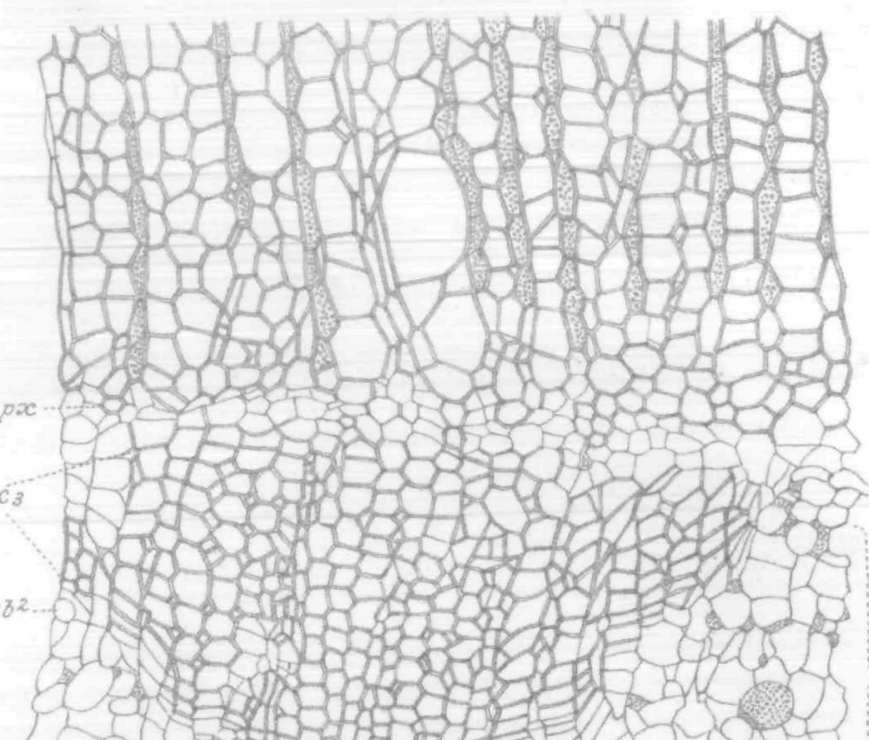
$p \hbar_{2}$

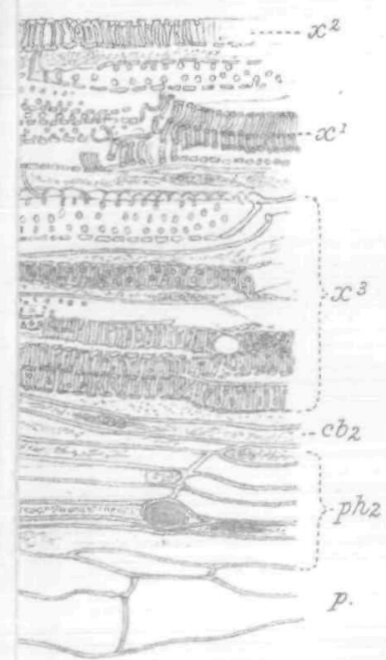

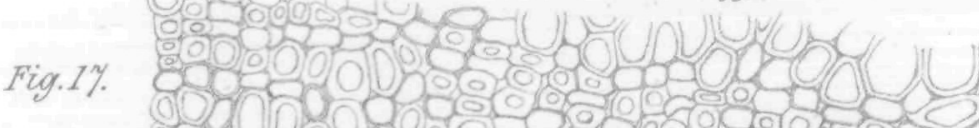
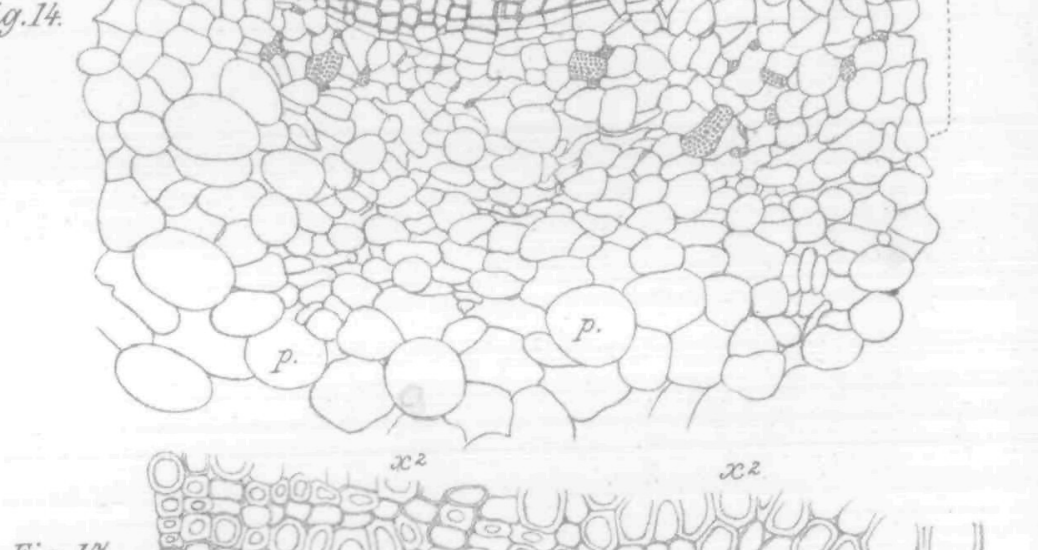

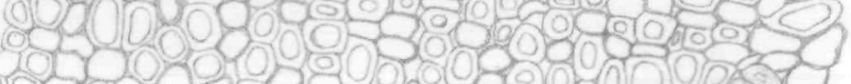

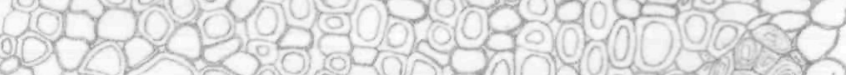

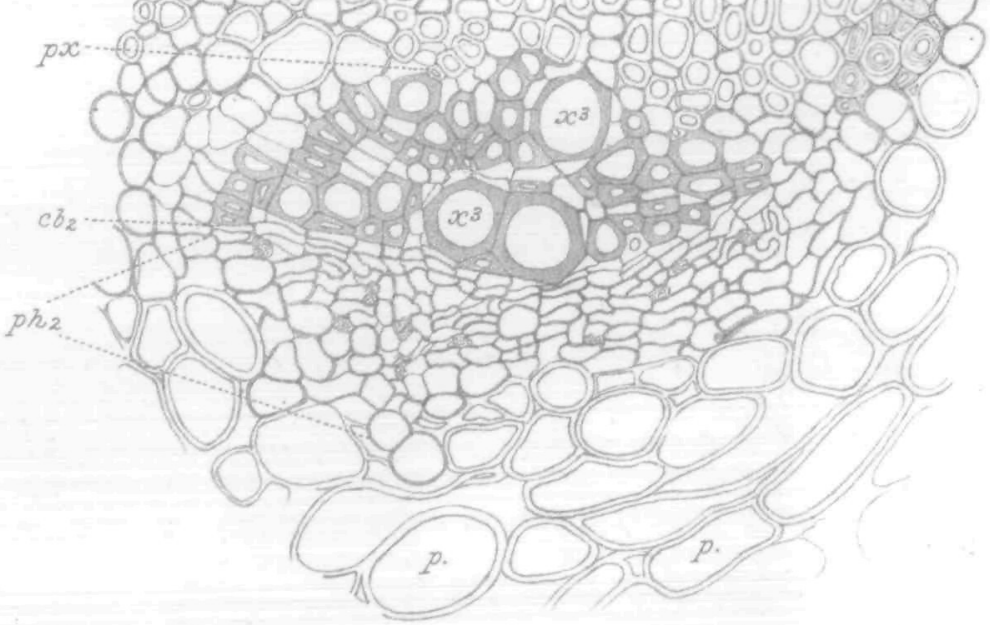


Fig. 19.

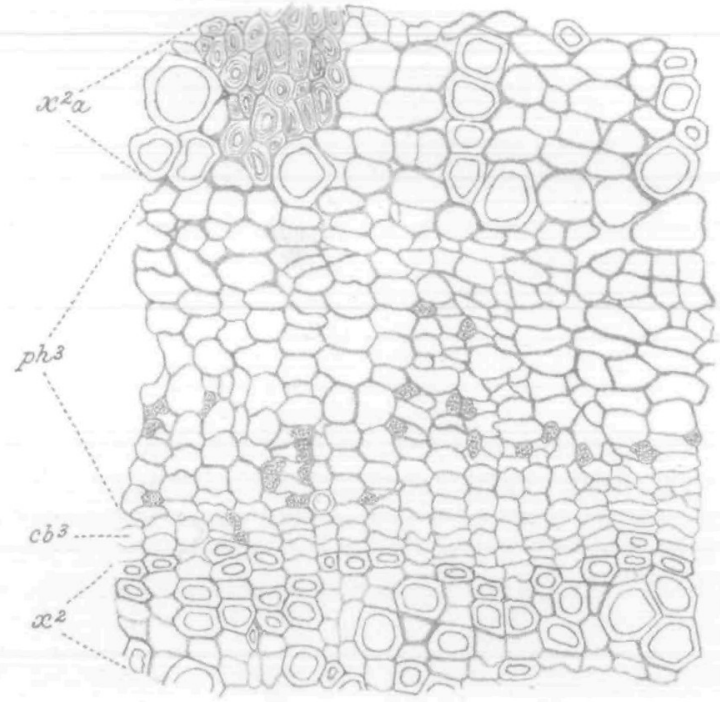

Fig. 20 .

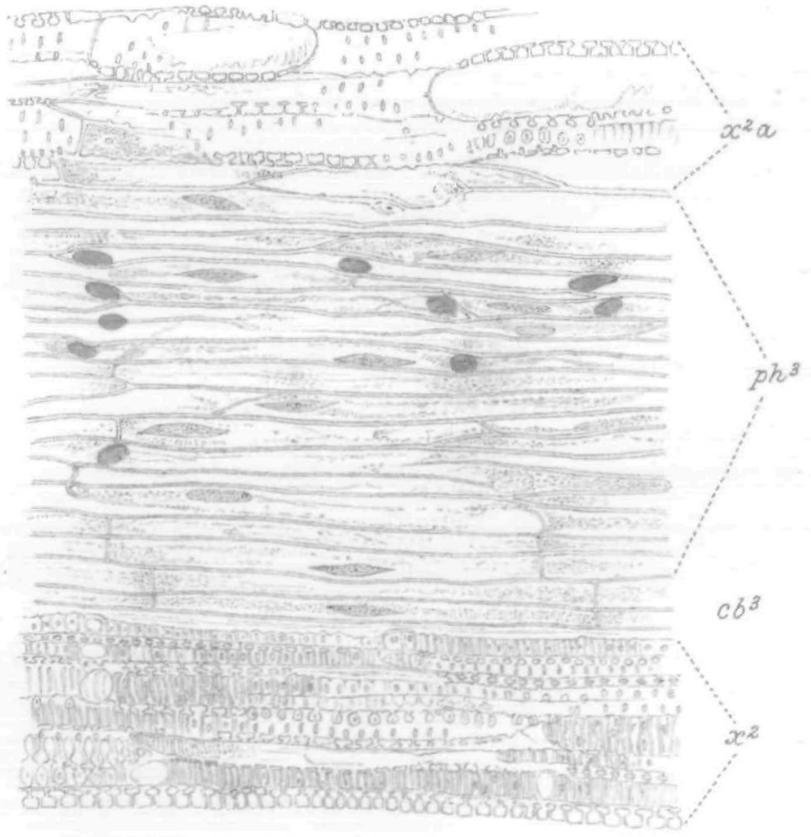

